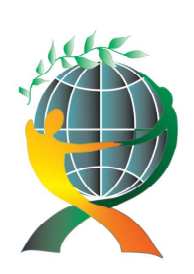

\author{
(online) $=$ ISSN $2285-3642$ \\ ISSN-L = $2285-3642$ \\ Journal of Economic Development, Environment and People \\ Volume 9, Issue 4, 2020
}

URL: http://jedep.spiruharet.ro

e-mail: office jedep@spiruharet.ro

\title{
Quantitative Research: A Successful Investigation in Natural and Social Sciences
}

\author{
Haradhan Kumar MOHAJAN ${ }^{1}$ \\ Assistant Professor, Department of Mathematics, Premier University, Chittagong, Bangladesh
}

\begin{abstract}
Research is the framework used for the planning, implementation, and analysis of a study. The proper choice of a suitable research methodology can provide an effective and successful original research. A researcher can reach his/her expected goal by following any kind of research methodology. Quantitative research methodology is preferred by many researchers. This article presents and analyzes the design of quantitative research. It also discusses the proper use and the components of quantitative research methodology. It is used to quantify attitudes, opinions, behaviors, and other defined variables and generalize results from a larger sample population by the way of generating numerical data. The purpose of this study is to provide some important fundamental concepts of quantitative research to the common readers for the development of their future projects, articles and/or theses. An attempt has been taken here to study the aspects of the quantitative research methodology in some detail.
\end{abstract}

Keywords: Research methodology, quantitative research, numerical analysis, ethics

JEL Codes: B16, B23, C83

How to cite: Mohajan, H. (2020). Quantitative Research: A Successful Investigation in Natural and Social Sciences. Journal of Economic Development, Environment and People, 9(4). doi:http://dx.doi.org/10.26458/jedep.v9i4.679

\section{Introduction}

Research is a systematic and organized effort to investigate a specific problem to provide a solution. The aim of it is to add new knowledge, develop theories as well as gathering evidence to prove generalizations [Sekaran, 2000]. Research can be classified into three basic categories as [Swanson \& Holton, 2005; Kothari, 2008; Creswell, 2011]: 1) quantitative research, 2) qualitative research, and 3) mixedmethod research. Each of these methods plays important role in the research area. Researchers choose any one of the above three types of research methods according to the research aim, the objectives, the nature of the topic, and the research questions to identify, collect and analyze information [Goertz \& Mahoney, 2012].

Quantitative research is a formal, objective, rigorous, deductive approach, and systematic strategies for generating and refining knowledge to problem-solving [Burns \& Grove, 2005]. Its designs are either

\footnotetext{
${ }^{1}$ Email: haradhan1971@gmail.com

Tel: +8801716397232
} 


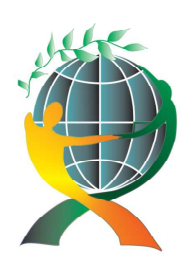

\author{
(online) $=$ ISSN $2285-3642$ \\ ISSN-L = $2285-3642$ \\ Journal of Economic Development, Environment and People \\ Volume 9, Issue 4, 2020
}

URL: http://jedep.spiruharet.ro

e-mail: office jedep@spiruharet.ro

experimental or non-experimental and seek to obtain accurate and reliable measurements [Rahman, 2017]. It consists of systematic observation and description of the characteristics or properties of objects or events to discover relationships between an independent (predictor) variable and a dependent (outcome) variable within a population [Best, 1981]. The word "quantitative" means quantity or amounts (how many) information collected in the course of the study and is in a quantified or numeric form, i.e., in statistical supports, often using software, such as Excel, Access, SPSS, Python, SAS, JMP, R or Stata [White \& Millar, 2014]. Quantitative research explains phenomena by collecting numerical unchanging detailed data that are analyzed using mathematically based methods, in particular statistics that pose questions of who, what, when, where, how much, how many, and how. It deals in numbers, logic, and an objective stance. It is original research in which the researcher decides what to study, asks a specific, narrow question, collects quantifiable data from participants, analyze these numbers using statistics, and conducts the inquiry in an unbiased, objective manner [Creswell, 2011]. It considers interpersonal relationships, personal values, meanings, beliefs, thoughts, and feelings with human beings. It manipulates variables and control natural phenomena [Rarner, 1989].

Quantitative research appeared around 1250 and was driven by investigators with the need to quantify data. Since then quantitative research has dominated western culture as the research method to create new knowledge. This method was originally developed in the natural sciences to study natural phenomena [Williams, 2007]. In quantitative research, a variable is a factor that can be controlled or changed in an experiment [Wong, 2014]. It deals with quantifying and analyzing variables to get results. It is strictly positivistic, objective, scientific, and experimental. It should be used when, a highly structured research design is needed and can be naturally imposed on the experiment being conducted, the researcher needs to be totally objective; is not part of what he(s) observes, and does not bring his/her own interests, values, or biases to the research, and although the phenomena being captured may be complex, they can be broken down and assigned some type of numerical value [Chen, 2011].

Quantitative research methods dealing with numbers and anything that are measurable in a systematic way of investigation of phenomena and their relationships. It is used to answer questions on relationships within measurable variables with an intention to explain, predict, and control a phenomenon [Leedy, 1993]. In quantitative research, researchers decide what to study, ask specific and narrow questions, collect quantifiable data from participants, analyze these numbers using statistics, and conducts the inquiry in an unbiased and objective manner. At present two-thirds of research, articles are published by the use of quantitative data, which are highly valid and provide a high level of research quality. The analysis of information from large samples almost inevitably requires quantitative methods [Hunter \& Leahey, 2008].

In quantitative research statistical, mathematical, or computational techniques are applied to obtain accurate results. Recently this type of research is widely used in business studies, natural sciences, mathematical sciences, and social sciences. The quantitative research data are collected through closedended questionnaires. The type of data is in numerical forms, such as statistics, percentages, graphs, etc. The data are used to develop and employ models based on the form of mathematical models, theories, and hypotheses to obtain the desired result. A research hypothesis is an empirically testable statement that is generated from a proposition, which is a clearly stated relation between independent and dependent variables [Given, 2008].

In the quantitative methodology, researchers use the scientific method that starts with the specific theory and hypotheses for research procedures. They attempt to achieve rich, real, deep, and valid data. 


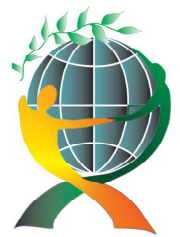

\author{
(online) $=$ ISSN $2285-3642$ \\ ISSN-L = $2285-3642$ \\ Journal of Economic Development, Environment and People \\ Volume 9, Issue 4, 2020 \\ URL: http://jedep.spiruharet.ro \\ e-mail: office jedep@spiruharet.ro
}

They observe the world as objective and seek measurable relationships among variables to test and verify their study hypotheses [Swanson \& Holton, 2005]. However, the last 40-50 years have witnessed an uprising of the qualitative and quantitative research approaches particularly in the fields of sociology, education, and some new disciplines, such as economics, psychology, political science, community health, health and human development, female studies, demography, nursing science, and business studies in the form of sociological tradition [Creswell, 2011]. The findings from quantitative research can be predictive, explanatory, and confirming [Williams, 2007]. The objective of quantitative research is to develop and use mathematical models, theories, and hypotheses/propositions pertaining to phenomena [Given, 2008].

\title{
2. Literature Review
}

The literature review is an introductory section where the investigator needs to determine what is known and not known about the problem, identify knowledge gaps, establish the significance of the study and situate the study within existing knowledge [Polit \& Hungler, 2013]. Meredith E. Young and Anna Ryan describe the ontology, epistemology, methodologies, axiology, signs of rigor, and common critiques of postpositivism in health professions education [Young \& Ryan, 2020]. Jacob Kola Aina reviewed two types of constructivism: social and cognitive constructivism for effective physics teaching [Aina, 2017]. Douglas Warfield indicates that the evolution of information systems and information technology (IS/IT) has fueled the battle of research methodologies among researchers, predominantly caused by the foundations of social sciences and computer technology that combine to form the business and technology application of IS/IT [Warfield, 2013].

James Mahoney and Gary Goertz have suggested that quantitative and qualitative research traditions can be thought of as distinct cultures marked by different values, beliefs, and norms. They have adopted these research traditions in ten areas as approaches to explanation, conceptions of causation, multivariate explanations, equifinality, scope, and causal generalization, case selection, weighting observations, substantively important cases, lack of fit, and concepts and measurement [Goertz \& Mahoney, 2012]. ChaoChien Chen studies the appropriateness of using a quantitative research methodology that will examine several aspects of beep baseball as a way for the visually-impaired to lead more enjoyable leisure lives [Chen, 2011].

Mohammad Ali Disman and M. Syaom Barliana discuss the weaknesses in doctoral research, particularly data analysis and hypothesis testing by the use of statistical methods in the quantitative approach [Disman \& Barliana, 2017]. Suphat Sukamolson introduces some important fundamental concepts, such as types and assumptions, advantages, common misconceptions, etc. of quantitative research [Sukamolson, 2007]. Ochieng Pamela Atieno investigates the strengths and weaknesses of qualitative research and provides probable suggestions to overcome these limitations by the use of quantitative research [Atieno, 2009]. Md Shidur Rahman discusses the advantages, disadvantages, and ethical issues of qualitative and quantitative researches of language "testing and assessment". He stresses that quantitative research is dominant in the context of language testing and assessment research [Rahman, 2017]. André Queirós, Daniel Faria, and Fernando Almeida analyze the strengths and limitations of both qualitative and quantitative methodologies to obtain accurate and reliable measurements. According to them, both methodologies offer a set of methods, potentialities, and limitations that must be explored and known by researchers [Queirós et al., 2017].

Susanna Loeb and her coauthors present a guide for more effectively approaching, conducting, and communicating quantitative descriptive analysis, which is a critical component of the scientific process. 


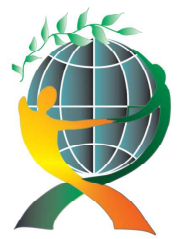

\author{
(online) $=$ ISSN $2285-3642$ \\ ISSN-L = $2285-3642$ \\ Journal of Economic Development, Environment and People \\ Volume 9, Issue 4, 2020 \\ URL: http://jedep.spiruharet.ro \\ e-mail: office jedep@spiruharet.ro
}

They also recommend for improving the ways in which quantitative descriptive findings are communicated throughout the education and research communities [Loeb et al., 2017]. Eyisi Daniel has shown a reason that although qualitative and quantitative research methods are different both of them are useful in research for problem-solving and to seek truth for the development of research. He has also discussed the advantages, disadvantages, strengths, and weaknesses of both methods in some detail [Daniel, 2016]. In a review paper, Haradhan Kumar Mohajan has discussed the reliability and validity of good research that increase transparency, and decrease opportunities to insert researcher bias in qualitative research [Mohajan, 2017]. In another paper, he has studied the background of the qualitative research methodology in social sciences and some other related subjects [Mohajan, 2018a].

Lydell $\mathrm{H}$. Hall tries to determine a correlation between transformational leadership behavior exhibited by the leadership team and job satisfaction among California card room casino employees. He also attempts to find a correlation between transformational, transactional, or laissez-faire leadership styles exhibited by the leadership team and job satisfaction among California card room casino employees. He has found that in the first case employees are in a higher level of job satisfaction but, in the second case, they show a negative attitude toward job satisfaction [Hall, 2018]. Moses Kumi Asamoah reexamines the limitations and uses of correlational studies [Asamoah, 2014].

Edith de Leeuw, Joop Hox, and Don Dillman have discussed aspects of survey research [de Leeuw et al., 2008]. Maninder Singh Setia states that in a cross-sectional study, the investigator measures the outcome and the exposures in the study participants at the same time. He adds that the participants just are selected based on the inclusion and exclusion criteria set for the study [Setia, 2016]. Mo Wang and his coauthors attempt to clarify the conceptual, methodological, and practical issues that frequently emerge when researchers conduct longitudinal research [Wang et al., 2017]. Fernando Rajulton realizes that longitudinal data create many complexities, which is a great challenge to the researchers. He briefly discusses the historical development of ideas related to longitudinal studies [Rajulton, 2001]. David A Grimes and Kenneth F Schulz have realized that a cohort study is the best way to identify the incidence and natural history of a disease, and can be used to examine multiple outcomes after a single exposure [Grimes \& Schulz, 2002].

Nelson Pinheiro Gomes and her coauthors discuss the development and consolidation process of trend studies, as a transversal area with transdisciplinary characteristics that was developed in connection with the concepts and practices of cultural studies [Gomes et al., 2018]. Anthony D. Harris and his coauthors have performed quasi-experimental research in infectious diseases in the area of interventions aimed at decreasing the spread of antibiotic-resistant bacteria [Harris et al., 2004]. Ronald R. Powell discusses several evaluation methods, such as input measurement, output/performance measurement, impact/outcomes assessment, service quality assessment, process evaluation, benchmarking, standards, quantitative methods, qualitative methods, cost analysis, organizational effectiveness, program evaluation methods, and library and information (LIS) centered methods [Powell, 2006]. Monika Mueller and her coauthors study a systematic scoping review of published methodological recommendations on how to systematically review and meta-analyze observational studies. They have extracted and summarized recommendations on predefined key items, such as protocol development, research question, search strategy, study eligibility, data extraction, dealing with different study designs, risk of bias assessment, publication bias, heterogeneity, and statistical analysis [Mueller et al., 2018]. 


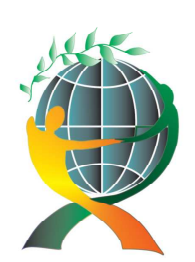

\author{
(online) $=$ ISSN $2285-3642$ \\ ISSN-L = $2285-3642$ \\ Journal of Economic Development, Environment and People \\ Volume 9, Issue 4, 2020
}

URL: http://jedep.spiruharet.ro

e-mail: office jedep@spiruharet.ro

\title{
3. Methodology of the Study
}

Word 'research' is comprised of two syllables, re- and search. Here re-means again, anew or over again, and search is a verb to examine closely and carefully, to test and try, or to probe. Together they form a noun describing a careful, systematic, patient study and investigation in some field of knowledge, undertaken to establish facts or principles [Grinnell, 1993]. Research is a diligent search, scholarly inquiry, investigation aimed at the discovery of new facts and findings. It may relate to any subject of inquiry about the collection of information, interpretation of facts, and revision of existing theories or laws in the light of new facts or evidence [Adams et al., 2007]. It is a systematic and organized effort to investigate a specific problem to provide a solution [Sekaran, 2000]. It also emphasizes creativity that is carried in a systematic way to improve knowledge which consists of human knowledge, culture, and society [OECD, 2002]. The research process usually consists of research stages, such as defining research questions, collect data, data processing, answer the research questions, and present the findings [Goertz \& Mahoney, 2012].

'Method' is a word coined of two Greek elements: meth- and odos. The meth- is an element meaning 'after', odos means 'way'. A method is, therefore, a following after the way that someone found to be effective in solving a problem, of reaching an objective, in getting a job done [Leedy \& Ormrod, 2001]. Greek element ology means 'the study of'. Hence, research methodology is the systematic procedure adopted by researchers to solve a research problem that maps out the processes, approaches, techniques, research procedures, and instruments. It may be understood as a science of studying how research is done scientifically [Kothari, 2008]. The methodology is a system of explicit rules and procedures in which research is based and against which claims of knowledge are evaluated [Ojo, 2003]. Research methodology helps to identify research areas and projects within these areas [Blessing et al., 1998]. Hence, research methodology is the systematic procedure adopted by researchers to solve a research problem that maps out the processes, approaches, techniques, research procedures, and instruments. It may be understood as a science of studying how research is done scientifically [Kothari, 2008].

According to John W. Creswell quantitative research originated in the physical sciences, particularly in chemistry and physics [Creswell, 2011]. It is based on testing a theory, measured with numbers, and analyzed using statistical techniques. It deals to quantify and analyze variables to get accurate results. It emphasizes objectivity and reproducibility, and a researcher can reach one's goal easily [Smith, 1975]. Quantitative research acts for data collection which is typically numeric and the researcher wants to use mathematical models as the methodology of data analysis [Williams, 2007]. In this study, we have used secondary data to enrich this paper. It can identify the domain, selection, design, and inclusion of various measuring variables in any research. For the collection of secondary data we have used both published and unpublished data sources. The published data are collected from books of famous authors, websites, national and international journals, e-journals, various publications of international organizations, handbooks, theses, magazines, newspapers, various statistical reports, historical documents, information on the internet, etc. On the other hand, the unpublished data are collected from diaries, letters, unpublished biographies and autobiographies of scholars, and various public and private organizations.

In this study, we have discussed the aspects of quantitative research which include research design, test and measurement procedures, and statistical analysis. To understand the current knowledge in research of quantitative methodology we have adopted narrative reviews of well-known scholars. The research methodology ultimately determines validity in the research and the value of the research. Reliability and 


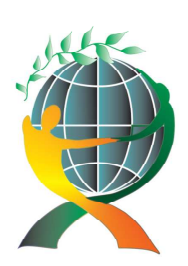

\author{
(online) $=$ ISSN $2285-3642$ \\ ISSN-L = $2285-3642$ \\ Journal of Economic Development, Environment and People \\ Volume 9, Issue 4, 2020 \\ URL: http://jedep.spiruharet.ro \\ e-mail: office jedep@spiruharet.ro
}

validity are inevitable issues in any research. Quantitative research is more reliable than other researches. Quantitative methodology is judged for rigor and strength based on validity, reliability, and generalizability [Morris \& Burkett, 2011].

It eliminates or attempts to eliminate extraneous variables within the internal structure of the study, and the data produced can also be assessed by standardized testing [Duffy, 1985]. We have tried to discuss various types of quantitative research; experimental research (pre-experimental, truly experimental, and quasi-experimental) and non-experimental research, such as descriptive research (observation studies, correlational research, and survey research), evaluation research, existing data, meta-analysis, causalcomparative research, etc. In this study, we have tried our best to maintain reliability and validity throughout the research. We have also taken attempts to enrich the article by highlighting the characteristics, advantages and disadvantages, strengths, and weaknesses of quantitative research.

\title{
4. Objective of the Study
}

The leading objective of this study is to represent the quantitative research methodology in natural and social sciences. The other specific objectives are as follows:

- To provide a historical background of quantitative research.

- To discuss steps, research design, and types of quantitative research.

- To highlight the characteristics, strengths and weaknesses, advantages, and disadvantages of quantitative research.

\section{Historical Background}

Every modern research is based on two main epistemological orientations: postpositivism and constructivism. Over the years, there are always different opinions among constructivists and positivists. But each has its own unique way of gathering and analyzing data. Neither constructivists nor positivists have claimed that their instruments are more reliable and valid than the other. The objective of each type of researcher is to achieve the same goal, i.e., to prepare fruitful research for the welfare of the society [Robson, 2002; Creswell, 2011; Daniel, 2016]. Four distinct paradigms that are related to social researches are constructivism, critical theory, positivism, and postpositivism. Constructivism and critical theory are related to qualitative research, while positivism and postpositivism are related to quantitative research [Lincoln \& Guba, 1985; Daniel, 2016].

Sir Isaac Newton, Henry de Saint-Simon, Auguste Comte, Karl Popper, etc. scholars contributed the positivistic idea of the absolute truth of knowledge in research. French philosopher Auguste Comte (17981857), the founder of positivism, adapted the methodology of the natural sciences (e.g., physics, biology, chemistry, etc.) for use in the social sciences and called his theory "positivism". Positivism is defined as a scientific methodology that aims to reach the laws of human behavior and social life [Kincheloe \& Tobin, 2009]. Positivistic researches are founded on a belief that the study of human behavior should be conducted in the same way as studies conducted in the natural sciences [Collis \& Hussey, 2009].

Positivism is a position in the philosophy of science that emphasizes the importance of observation for the growth of knowledge. The main purpose of positivism is to reach objective truth, facts, and laws. In the positivist belief, there is a truth that science can observe, measure, and describe. Positivist research 


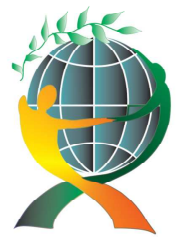

\author{
(online) $=$ ISSN $2285-3642$ \\ ISSN-L = $2285-3642$ \\ Journal of Economic Development, Environment and People \\ Volume 9, Issue 4, 2020
}

URL: http://jedep.spiruharet.ro

e-mail: office jedep@spiruharet.ro

advances through research proving or supporting a hypothesis [Popper, 2005]. Positivism seeks universal laws that govern behavior, and argues an objective external reality can be accurately and thoroughly understood. The positivist's belief that there is a truth that science can observe, measure, and describe [Park et al., 2020]. A positivist emphasizes quantitative methods, while a postpositivist considers both quantitative and qualitative methods to be valid approaches [Popper, 1963]. Historians identify two types of positivism: classical positivism that is an empirical tradition, and logical positivism that is most strongly associated with the Vienna Circle [Alexander, 1995]. Positivism is widely applied in the natural sciences, where empirical observation is used to make theories and models [Fox, 2008].

Positivistic attempts seek to identify, measure, and evaluate any phenomena and provide a rational explanation for it that establish causal links and relationships between the different variables of the subject and relate them to a particular theory [Collis \& Hussey, 2009]. The positivist approach is acquired its methods from social and education research and consists of the following steps [Xining, 2002]: i) creating a hypothesis, ii) establishing variables (sampling) and measurement devices, iii) data collection, iv) data analysis, and v) conclusion. The quantitative approach has its origin in positivistic epistemology, which is an approach to the study of people that commend the application of the scientific method [Bryman, 2012].

The word "postpositivism" is named for the first time by Denis Charles Phillips [Phillips \& Burbules, 2000]. Robert Dubin describes the basic components of a postpositivist theory [Zammito, 2004]. Famous philosophers Karl Popper, Willard Van Orman Quine, and Thomas Kuhn have been highly influential and led to the development of postpositivism. It is a metatheoretical stance that critiques and amends positivism. Postpositivists argue that theories, hypotheses, background knowledge, and values of the researcher can influence by the observational data. According to postpositivism, the world works according to fixed laws of cause and effect [Phillips \& Burbules, 2000]. For postpositivists, science is slow, progressive, iterative, theory refining, and characterized by attempts to advance through proving a theory wrong or incomplete. A postpositivist believes in a single objective, external, tangible, measurable reality, adopting a perspective aligned with scientific realism but truth or the understanding of reality remains incomplete or probabilistic [Letourneau \& Allen, 1999]. The key elements of post positivistic knowledge are [Creswell, 2011]: i) determinism, ii) theory verification, iii) empirical observation and measurement, and iv) reductionism (reality is reduced to small elements, such as variables, hypotheses, research questions, etc.).

Constructivism is a theory in education that recognizes the learners' understanding and knowledge based on their own experiences prior to entering school [Nola \& Irzik, 2006]. It emphasizes the importance of knowledge, beliefs, and skills for learning and research. It indicates that people construct their understanding and knowledge of the world through experiencing things and reflecting on those experiences [Garbett, 2011]. Jean Piaget is the founder of constructivism. He has identified impressionable and developmental aspects of human thought processes. Karl Mannheim first time thinks on constructivism (interpretive), and later has been elaborated on in the works of Yvonna Sessions Lincoln and Egon G. Guba [Lincoln \& Guba, 1985].

Constructivism indicates that knowledge is created by people through the interpretation and understanding of phenomena in social and historical perspectives. It is typically seen as an approach to qualitative research. Social constructivism is developed by Lev Semyonovich Vygotsky who argued that learning is a social and collaborative activity where people create meaning through their interactions among them [Aina, 2017]. Social constructivists believe that individuals seek an understanding of the world in which they live and work. The main elements of constructivist thinking are [Lincoln \& Guba, 1985; 


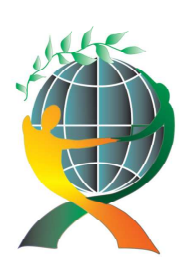

\author{
(online) $=$ ISSN $2285-3642$ \\ ISSN-L = $2285-3642$ \\ Journal of Economic Development, Environment and People \\ Volume 9, Issue 4, 2020 \\ URL: http://jedep.spiruharet.ro \\ e-mail: office jedep@spiruharet.ro
}

Creswell, 2011]: i) understanding, ii) multiple participant meanings, iii) social and historical construction, iv) inductive reasoning, and $v$ ) theory generation.

\title{
6. Quantitative Research Design
}

A hypothesis is a tentative explanation that accounts for a set of facts and can be tested by further investigation. Quantitative researchers design studies that allow testing the hypotheses. There are three kinds of variables in quantitative research: i) dependent variables, ii) independent variables, iii) extraneous or confounding variables. The variables that are hypothesized to depend on or be caused by other variables, i.e., monitors how subjects react by measuring response in one or more outcome measures are dependent variables, the variables that are believed to be the cause or influence, i.e., the researcher manipulates one or more of the variables, are independent variables, and the variables that are confusing or confound the relationship between the dependent and independent variables are extraneous variables. Dependent variables are influenced by one or more independent variables. For example, in healthcare wound healing is a dependent variable, type of dressing is an independent variable, and patient age and presence of diabetes mellitus are extraneous/confounding variables. Smoking is the independent variable and lung cancer is the dependent variable [White \& Millar, 2014]. When variables are clearly defined and numerical data are prepared, and then we can use quantitative research properly, i.e., it tests objective theories by examining the relationship among variables [Polit \& Hungler, 2013].

\section{Steps of Quantitative Research}

The quantitative research process generally consists of five steps to perform the research efficiently as [Swanson \& Holton, 2005; Kumar, 2011]: Formulating a research problem is a first and most important step in the research process. It identifies the destination of a researcher [Kumar, 2011]. It determines the basic questions that the researcher intends to answer with the research study. These questions describe factors or variables of interest to the researcher [Swanson \& Holton, 2005]. In the second step, the researcher determines the human participants in the study, which capitalizes on the advantage of using statistics to make inferences about larger groups using very small samples [Cooper \& Schindler, 2008]. In the third step, the researcher tries to select methods to answer questions, identifies variables, measures, and the research design to use in formulating specific research questions, methods, and participants of the study [Warfield, 2013]. In the fourth step, the researcher selects statistical analysis tools for analyzing the collected data. In the statistical analyses, the researcher determines how the variables describe, compare, associate, predict and contribute to explain the analysis results and to answer the propositions of the study [Cooper \& Schindler, 2008]. In the fifth step, the researcher performs the interpretation of the results of the analysis based on the statistical significance determined [Swanson \& Holton, 2005].

These five steps are used in quantitative research for generalization to the entire population for the coding of observations to accurate measurements. Then statistical methodologies are used to include activities that researchers want to conclude operation [Warfield, 2013].

\section{Types of Quantitative Research}

The quantitative research can be classified as [Cohen et al., 2000; Leedy \& Ormrod, 2001; Borbasi \& Jackson 2012]: i) experimental, and ii) non-experimental research. 


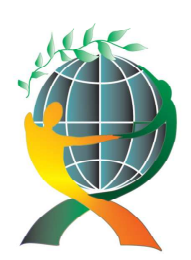

\author{
(online) $=$ ISSN $2285-3642$ \\ ISSN-L = $2285-3642$ \\ Journal of Economic Development, Environment and People \\ Volume 9, Issue 4, 2020
}

URL: http://jedep.spiruharet.ro

e-mail: office jedep@spiruharet.ro

\title{
8.1 Experimental Research
}

Experimental research is the most familiar type of research design for individuals in the physical sciences and some other related fields. It tries to reduce all kinds of biases as much as possible [Nunan, 1992]. It indicates how the observations or measurements should be obtained to answer a query in a valid, efficient, and economical way. It is referred to a hypothesis testing or a deductive research method. It seeks to determine a relationship between a dependent and an independent variable. The results of it are not known in advance. It is the process of planning a study to meet specified objectives. Here one or more independent variables are manipulated and applied to one or more dependent variables to measure their effects on the latter. In this type of research, the researchers design the specific conditions to test their theories or propositions, controlling the experiment and collecting their data to isolate the relationships between their defined independent variables and dependent variables [Swanson \& Holton, 2005]. It consists of making an observable and quantifiable change in the independent variable and then observing how that affects the dependent variables [Leedy \& Ormrod, 2001]. During the experimental research, the researcher investigates the treatment of an intervention into the study group and then measures the outcomes of the treatment. Experiments consist of making an observable and quantifiable change in one variable (the independent variable) and then observing how that affects other variables (the dependent variables) [Chen, 2011].

The goal of it is to test a hypothesis to establish cause and affect relationships [Ary et al., 2010]. Some advantages of experimental research are [Mildner, 2019]: It controls the independent variables. It is a straightforward determination of causal relationships, the possibility of verifying results through repeatability/replicability, and the opportunity to create conditions that are not easily observed in natural settings or would take too long. Some disadvantages of experimental research are [Mildner, 2019]: It is unnatural; difficult to apply the results to real-life situations, and ethical considerations. It cannot be applied to all types of research problems, and results may appear significant because of experimenter error or the inability to control for all extraneous variables. There are three types of exploratory approaches: preexperimental, truly experimental, and quasi-experimental [Leedy \& Ormrod, 2001; Ary et al., 2010].

The pre-experimental research involves an independent variable that does not vary or a control group that is not randomly selected. It follows pre-test and post-test to see the result of the treatment but fails to include a control group [Campbell \& Stanley, 1963; Ary et al., 2010].

The true experimental approach provides a higher degree of control in the experiment and produces a higher degree of validity. It is first described by D. T. Campbell [Campbell, 1957]. It is a systemic approach to quantitative data collection involving mathematical models in the analyses [Campbell \& Stanley, 1963]. It examines the cause and effect relationships between independent and dependent variables under highly controlled conditions. It has both pre- and post- tests, experimental and control groups, and random assignments of subjects [Nunan, 1992]. It must enable the researcher to maintain control over the situation in terms of assignment of subjects to groups, in terms of who gets the treatment condition, and in terms of the amount of treatment condition that subjects receive [Christensen, 1988].

The word "quasi" means partial, half, or pseudo. The quasi-experimental design involves a non-random selection of study participants, where control is limited and true experimentation is impossible or difficult [Harris et al., 2004]. It has both pre-and post-test and experimental and control groups, but no random assignments of subjects. Since the variable cannot be controlled, validity may be sacrificed [Campbell \& Stanley, 1963]. For example, two sick people of the same age and same physical structure are given the 


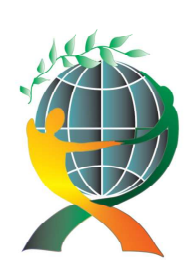

\author{
(online) $=$ ISSN $2285-3642$ \\ ISSN-L = $2285-3642$ \\ Journal of Economic Development, Environment and People \\ Volume 9, Issue 4, 2020 \\ URL: http://jedep.spiruharet.ro \\ e-mail: office jedep@spiruharet.ro
}

same antibiotic, and one of them is given an additional antibiotic with the common antibiotic. After seven days the two patients are examined, and their health condition is measured. The lack of random assignment is the major weakness of quasi-experimental research. The statistical association does not imply causal association if the study is poorly designed [Harris et al., 2004].

\title{
8.2 Non-Experimental Research
}

It lacks the manipulation of an independent variable, random assignment a researcher simply measure variables as they occur. Non-experimental research is divided into the descriptive, causal-comparative, evaluation, existing data, meta-analysis, etc. approaches.

\subsubsection{Descriptive Research}

Quantitative research methods fall under the broad heading of descriptive research. It is used when little is known about a particular phenomenon [Walker, 2005]. Descriptive research is widely used in education, epidemiology, nutrition, and the behavioral sciences. It tries to gather information about prevailing situations for the purpose of description and interpretation [Aggarwal, 2008]. It defines the research aspects viz., who, what, where, when, why and sometimes how of the research which should be thought of as a means to an end rather than an end, itself [Yin, 1994]. The goal of this type of research is to identify and describe trends and variations in populations, creates new measures of key phenomena, or describes samples in studies aimed at identifying causal effects [Loeb et al., 2017].

Descriptive research depicts an accurate profile of people, events, or situations [Robson, 2002]. It refers to the type of research question, design, and data analysis that will be applied to a given topic. It examines a phenomenon that is occurring at a specific place and time. It is concerned with conditions, practices, structures, differences, or relationships that exist, opinions held evident processes. It gathers and analyzes empirical data, and then organizes, tabulates, depicts, and describes the data collection and attempts to develop knowledge [Glass \& Hopkins, 1984; Best \& Kahn, 2007].

It can be statistical research and tries to study frequencies, averages, and other statistical calculations. It generates data, both qualitative and quantitative, that define the state of nature at a point in time. It attempts to describe, explain, and interpret the conditions of the present [Koh \& Owen, 2000].

It is a basic research method that examines the current situation. It identifies the characteristics of an observed phenomenon or explores correlations between two or more entities, and nothing is controlled or manipulated. In this type of research, a researcher can collect a large amount of data. It cannot be used as the basis of a causal relationship where one variable affects another. It is sometimes contrasted with hypothesis-driven research, which is focused on testing a particular hypothesis by means of experimentation [Casadevall \& Fang, 2008]. The three types of descriptive research are observation studies, correlational research, and survey research.

Observation Studies: Observation study is one of the most important research methods in natural and social sciences, and has been used for collecting data about people, processes, and cultures in qualitative research. It is used for referring several different types of non-experimental studies in which behavior is systematically observed and recorded. It is an ethnographic research method and it seems that there is no specific beginning of it. But some researchers stated that use of it was started in the late $19^{\text {th }}$ and beginning of the $20^{\text {th }}$ centuries [Baker, 2006]. The Greek philosopher Aristotle used observational techniques in his botanical studies on the island of Lesbos. Auguste Comte (1798-1857), the father of sociology, listed 


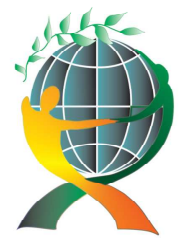

\author{
(online) $=$ ISSN $2285-3642$ \\ ISSN-L = $2285-3642$ \\ Journal of Economic Development, Environment and People \\ Volume 9, Issue 4, 2020 \\ URL: http://jedep.spiruharet.ro \\ e-mail: office jedep@spiruharet.ro
}

observation as one of the four core research methods [Adler \& Adler, 1994]. Observation is a preplanned research tool that is carried out purposefully to serve research questions and objectives. It is related to positivist research [Angrosino, 2005]. It enables the researcher to combine it with questionnaires and interviews to collect objective information [Johnson \& Turner, 2003]. Observation studies include the systematic recording of observable phenomena [Gorman \& Clayton, 2005].

Observation study is the least intrusive data collection method and can be an abuse of an individual's privacy [Adler \& Adler, 1994]. Observation data is collected by naturalistic inquiry using a structured, unstructured, or semi-structured approach [Fry et al., 2017]. An individual's privacy cannot be abused and a researcher must be unbiased during data collection. It is often criticized for lacking reliability [Adler \& Adler, 1994]. It is time-consuming, costly; practically challenging and a variety of techniques are used to collect data. For the collection of data a researcher needs specialized training on how to observe, what and how to record the data, how to enter the field and leave it, length of time in the field, sampling, and data collection techniques, etc. Hence it is a complex and challenging research method [Baker, 2006].

Direct observation is called the gold standard among qualitative data collection techniques [Murphy \& Dingwall, 2007]. Observation data collection can improve understanding of the practice, processes, knowledge, beliefs, and attitudes embedded in social interactions [Fry et al., 2017].

Some advantages of observational research are as follows [Foster, 2006]:

- research information can be revealed carefully, a planned observation by a researcher over a period of time,

- observational data seem more accurate,

- the observer sees but participants cannot,

- observation can provide information on those who cannot speak (e.g., babies, very young children and animals), and

- data collected from observation can check on, and supplement, information obtained from other sources.

There are some limitations to the observational research method as follows [Foster, 2006]:

- behavior of interest may be inaccessible and observation may simply be impossible if observation not usually permit,

- people sometimes consciously or unconsciously provide inaccurate information,

- researcher's preconceptions and existing knowledge will bias observation, and

- it is very time-consuming and costly.

Correlational Research: The term 'correlation' is a common and useful statistical concept applied in research. Francis Galton (1822-1911) for the first time provided the idea of correlation in 1898 but Karl Pearson (1857-1936) developed and promoted it as a scientific concept of universal significance [Aldrick, 1995]. It is a type of quantitative research method within the positivism paradigm. Mainly three types of correlational research have been identified: positive correlation, negative correlation, and no correlation research [Anderson \& Arsenault, 1998].

Correlational research describes what exists at the moment. It examines differences of characteristics or correlates two or more variables. In this type of research, there is no manipulation of variables [Queirós et al., 2017]. In quantitative research, it includes explaining phenomena by collecting numerical data that are analyzed using mathematically based statistical methods [Asamoah, 2014]. It is a type of non-experimental, backward-looking, and dynamic research where the researcher employs the data derived from preexisting variables. It provides an evaluation of the strength and direction of the relationship among variables. The 


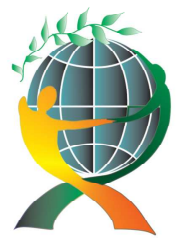

\author{
(online) $=$ ISSN $2285-3642$ \\ ISSN-L = 2285 - 3642 \\ Journal of Economic Development, Environment and People \\ Volume 9, Issue 4, 2020 \\ URL: http://jedep.spiruharet.ro \\ e-mail: office jedep@spiruharet.ro
}

goal of correlational research is to describe the relationship between variables and to measure the strength of the relationship [Ary et al., 2010].

A researcher will gather data to determine whether, and to what extent two or more quantifiable variables in a particular group. These data are numbers that reflect the measurement of the characteristics of research questions [Williams, 2007]. It plays an important role in the development and testing of theoretical models. The disadvantage of this research is that it just provides a relationship among variables; no calculations can be prepared regarding causality [Samuel \& Okey, 2015].

Survey Research: Among many types of quantitative research, survey research is very popular in the natural and social sciences, which includes questionnaires, personal interviews, phone surveys, and normative surveys. In a country, the survey is conducted for the economic, social, political, and cultural shape [Bethlehem, 2009]. It is the systematic gathering of information from respondents for the purpose of understanding and predicting some aspects of the behavior of the population of interest. The survey research was invented by Paul Lazarsfeld, George Gallup, and Hadley Cantril [Glasow, 2005; Sukamolson, 2007]. It focuses on people, the vital facts of people, their beliefs, opinions, attitudes, motivations, and behavior [Kerlinger \& Lee, 2000].

Survey research is a study on large and small populations by selecting samples chosen from the desired population and to discover relative incidence, distribution, and interrelations [Kerlinger \& Lee, 2000]. It provides an important source of basic scientific knowledge. It uses scientific sampling and questionnaire design to measure the characteristics of the population with statistical precision [Sukamolson, 2007]. It is the best method of data collection when the researcher is interested in collecting original data for a population that is too big to test directly [Babbie, 2001].

Generally, many researchers conduct survey studies, such as economists for income and expenditure patterns among households, educationists for factors influencing academic performance, health professionals for the implications of health problems on people's lives, psychologists for the roots of ethnic or racial prejudice, political scientists for comparative voting behavior, sociologists for the effects on the family life of women working outside the home, etc. [de Leeuw et al., 2008; Kothari, 2008; Creswell, 2011]. It is the most common type of descriptive research in dietetic, nutrition, and health areas, which involves asking questions of a sample of individuals who are representative of the group or groups being studied [Koh \& Owen, 2000].

The ultimate goal of survey research is to learn about a large population by surveying a sample of the population. In this method, a researcher poses a series of questions to the respondents, summarizes their responses in percentages, frequency distribution, and some other statistical approaches. It is concerned with sampling, questionnaire design, questionnaire administration, and data analysis. Survey research typically employs face-to-face personal interviews, telephone interviews, panels, observations, e-mail and internet interviews, or the common approach using questionnaires [McClosky, 1969; Mathers et al., 2009; Mathiyazhagan \& Nandan, 2010].

In survey, research biases may occur and respondents may have difficulty assessing their own behavior. It is unsuitable where an understanding of the historical context of phenomena is required [Pinsonneault \& Kraemer, 1993]. The survey does not show exact measurements; only provides estimates for the true population [Salant \& Dillman, 1994]. There are two types of surveys: cross-sectional survey and a longitudinal survey. The key difference between them is that the first one occurs once whereas the latter takes place on multiple occasions over time [Lynn, 2009]. 


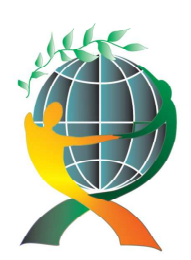

\author{
(online) $=$ ISSN $2285-3642$ \\ ISSN-L = $2285-3642$ \\ Journal of Economic Development, Environment and People \\ Volume 9, Issue 4, 2020
}

URL: http://jedep.spiruharet.ro

e-mail: office jedep@spiruharet.ro

Cross-Sectional Survey: A survey that is carried out at just one-point in time or over a short period is known as a cross-sectional or prevalence study. It is a type of observational study design. It is selected based on the inclusion and exclusion criteria set for the study. It is used for population-based surveys and to assess the prevalence of diseases in clinic-based samples [Ross \& Vaughan, 1986; Setia, 2016]. It provides a snapshot of what is happening in that group at that particular time. It is used in the study is descriptive and survey related. It sometimes investigates associations between risk factors and the outcome of interest [Levin, 2006]. It tells us what people are thinking or doing at one point in time. It is useful in assessing practices, attitudes, knowledge, and beliefs of a population concerning a particular health-related event [Buck, 2008]. If the research needs a pool of opinions and practices, a cross-sectional survey would be appropriate and collects information from a sample drawn from a population at one point in time. The period of data collection can vary and it depends on the study weightage [Ross \& Vaughan, 1986; Mathers et al., 2009].

Advantages of it are [Levin, 2006; Setia, 2016]: It is relatively inexpensive and usually be conducted relatively faster, there is no loss to follow-up, many outcomes and risk factors can be assessed. It is useful for public health planning, monitoring, and evaluation. Disadvantages of it are [Levin, 2006; Setia, 2016]: It is difficult to make a causal inference, only a snapshot is provided different results may happen another time. It is prone to incidence bias.

Longitudinal Survey: In 1759, Gueneau de Montbeillard first has recorded the longitudinal study, but in the 1920s the study has advanced when a monumental work was undertaken by Lewis M. Terman of Stanford University to study the developmental histories of gifted children [Buffon, 1837; Rajulton, 2001]. A longitudinal survey rather than taking a snapshot, paints a picture of events or attitudes over prolonged periods, often years or decades. It is used in social science, natural science, and health research (e.g., clinical pathology, public health, child development, adolescent psychosocial development, genetic classification, epidemiological case registers, etc.) to study rapid fluctuations in behaviors, thoughts, and emotions from moment to moment in processes in human and technical systems. It makes observing changes more accurate and is applied in various other fields [Venkatesh \& Vitalari, 1991; Carlson et al., 2009]. Organizational science researchers apply it to understand changes in organizational structure, causal mechanisms, and organizational adaptation [Tuma \& Hannan, 1984].

If a researcher specifies the objective to compare differences in opinion and practices over time, a longitudinal survey would be the ideal method and data collection is done at different points of time to observe the changes [Mathers et al., 2009]. The length of longitudinal study periods varies along with six parameters: length of study, number of data collection periods, duration between data collection efforts, method of data collection, research objectives, and unit of analysis [Venkatesh \& Vitalari, 1991].

Few advantages of longitudinal studies are [Lynn, 2009; Caruana et al., 2015]: It establishes a sequence of events, excludes recall bias in participants, tries to identify and relate events to particular exposures, and identifies change over time in particular individuals within the group. It enables researchers to identify patterns of change. It allows for the measure of stability or instability and the identification of causality. Few disadvantages of longitudinal studies are [Lynn, 2009; Caruana et al., 2015]: It is difficult the separation of the reciprocal impact of exposure and outcome, incomplete and interrupted follow-up of individuals may arise over time. It increases temporal and financial demands and difficulty in separation of the reciprocal impact of exposure and outcome. It continuously may lose respondents from the sample due to deaths, moving, and withdrawing from the research. Coverage errors may occur when there is a gap between the sampling frame and the total population, which increases with time. Three common types of longitudinal 


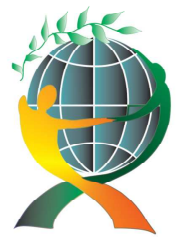

\author{
(online) $=$ ISSN $2285-3642$ \\ ISSN-L = 2285 - 3642 \\ Journal of Economic Development, Environment and People \\ Volume 9, Issue 4, 2020 \\ URL: http://jedep.spiruharet.ro \\ e-mail: office jedep@spiruharet.ro
}

surveys are cohort studies, panel studies, and trend studies. Panel and cohort studies are similar in that they track the same units over a period of time [Venkatesh \& Vitalari, 1991].

Cohort Studies: The word "cohort" has its origin in the Latin cohors, referring to warriors of 300-600man units in the Roman army [Samet \& Munoz, 1998; Grimes \& Schulz, 2002]. The history of the cohort study was in a 1988 review by F. D. K. Liddell and papers published from a 1983 American Cancer Society workshop on cohort studies. These researchers first discussed the terminology, the definitions, and the evolution of the cohort design [Liddell, 1988; NIH, 1997]. A cohort study is more difficult to carry out than a trend survey. Because after a long time some participants move house, some fall ill and die, and some just refuse to participate [Mathers et al., 2009].

A cohort study is the aggregate of individuals who experienced the same life event within the same time interval. In this study, the cohort is closed against new entries because such entries are impossible [Ruspini, 2002]. It tracks two or more groups forward from exposure to outcome. It provides the best way to make sure both the incidence and natural history of a disorder [Hulley et al., 2001]. Here a researcher specifies the population and lists the names of all members of this population. At each data collection point, a researcher will select a sample of respondents from the population of subordinates doing security audits and penetration testing and administer a questionnaire. This is then repeated at another point in time. It is particularly useful in tracking the progress of particular conditions over time, on the order of from 5 to 25 years or longer [Venkatesh \& Vitalari, 1991].

It has the accuracy of data collection with regard to exposures, confounders, and endpoints. It is useful to investigate multiple outcomes that might arise after single or multiple exposures in one cohort. For example, cigarette smoking (the exposure) can cause emphysema, oral cancer, stroke, and heart disease (the outcomes). In cohort studies, the hypothesis can be generated [Grimes \& Schulz, 2002; Euser et al., 2009]. It also reduces the risk of survivor bias; consequently, it is less biased. Its time-order is generally clear. It allows the calculation of incidence rates, relative risks, and confidence intervals. It has also some limitations, such as selection bias is built, generally require large samples, not possible to establish causal effects, loss to follow-up can be a difficulty, partitioning might be needed to avoid a blurring of exposure, sometimes termed contamination [Hulley et al., 2001; Grimes \& Schulz, 2002; Euser et al., 2009].

Panel Studies: The history of panel research begins in 1759, when Count Philibert Guéneau du Montbeillard began recording his son's stature every six months from birth to age 18 [Baltes \& Nesselroade, 1979). Modern panel research was established in the 1930s, when several classic studies of human growth and development began [Bogin, 1999]. The use of panel data was first introduced by F. Lazarsfeld in the 1940s in an analysis of public opinion, using market research gathered over time [Andreß, 2017]. In the last 60 years, panel study has increased in the social, life, medical, and public-health sciences on firms, countries, or other entities. It enhances our understanding of globalization, transnationalism, migration, and development of political-economic structures, acculturation, and intergenerational transmission of culture [Gravlee et al., 2009].

Panel survey provides an efficient and cost-effective means to measure changing behaviors and attitudes over time. It suggests that individuals, firms, states, or countries are heterogeneous. It has largescale research facilities for research on human behavior and attitudes in real-life settings [Andreß, 2017]. It is a method of direct extension of a questionnaire or interview survey and data are collected from the same people at two or more points in time. It is usually construed to be a short-term usually one to five years duration [Venkatesh \& Vitalari, 1991]. Remarkable panel studies have been conducted prior to 1970, but 


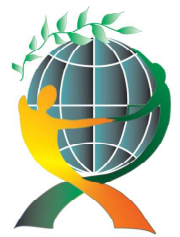

\author{
(online) $=$ ISSN $2285-3642$ \\ ISSN-L = $2285-3642$ \\ Journal of Economic Development, Environment and People \\ Volume 9, Issue 4, 2020
}

URL: http://jedep.spiruharet.ro

e-mail: office jedep@spiruharet.ro

major development has been made in the 1970s in the USA. Several other Western nations analyzed panel studies on large-scale in the 1980s [Duncan et al., 1987].

It generally samples the whole population rather than single years of age to understand the dynamics of change of the whole population, and its evolution over the lifetime of the study [Buck, 2008]. Here a researcher can identify a sample from the beginning and follow the respondents over a specified period of time to observe changes in specific respondents and highlight the reasons why these respondents have changed [Mathiyazhagan \& Nandan, 2010]. In fixed panel study data is collected from the same units on multiple occasions. Only deaths or emigration reduces the size of the eligible sample. Repeated panel study involves a series of panel surveys, which may or may not overlap in time. A split panel involves a combination of cross-sectional and panel samples at each wave of the study [Buck, 2008].

Advantages of panel surveys are: It is analytically strong and provides an opportunity to link macromicro issues. It constructs and tests more complicated behavioral models than purely cross-section data. It analyzes information collected on individuals and households repeatedly over time. It provides more informative data, more variability, less collinearity among the variables, more degrees of freedom, and more efficiency. It allows researchers to track changes in an individual's attitudes and behaviors over time if they wish to. It is better able to study the dynamics of adjustment. It encourages researchers to collect a considerable amount of information on the participants [Greaves, 2017; Andreß, 2017].

Disadvantages of panel surveys are: It is costly and complex. It takes a long time for results to become available. It takes a long-term investment that requires considerable financial and human resources. Overtime reduces sample size and can result in biased inferences. Interviews in earlier waves may influence interviews in subsequent waves; consequently, the actual value of a variable may change. Measurement errors may arise due to faulty responses of unclear questions, memory errors, deliberate distortion of responses, inappropriate informants' misreporting of responses, and interviewer effects [Lynn, 2009; Andreß, 2017].

Trend studies: Trend study is a transdisciplinary area that integrates concepts, perspectives, and methodologies from cultural studies, anthropology, marketing, design, etc. It gathers data from a particular population characterized by a specific variable and different samples from a population whose members may change are surveyed at different points of time [Gomes et al., 2018]. It is a guiding policy, expressed in concepts, leading cultural relevance to the various spheres of society. The direction of it tends to move, and the effect of which focuses on culture, society, or the business sector in which it develops. It can generate scenarios on society's evolution encompassing activities, attitudes, behaviors, and social concerns [Rech, 2016]. It is a forecast of something that will happen in a certain way and will be accepted by most people. It is an essential part of the emotional, physical, and psychological environment of the human being [Vejlgaard, 2008; Gomes et al., 2018]. Trends are driven according to basic needs, drivers of change, and innovations [Mason et al., 2015].

It takes repeated samples of different people each time but always uses the same core questions. It set out to measure trends in public opinion and behavior over time. It reveals the current situation of a specific research subject in a specific field by focusing on research topics, methodological approach, theoretical framework, etc. about that research subject [Ertem-Eray, 2019]. It focuses more on "why" rather than on "what". It is based on two foundations: cultural and commercial. It can generate scenarios on society's evolution, encompassing activities, attitudes, behaviors, and social concerns [Rech, 2016]. In addition to consumer trends, the other areas are: social, political, and economic; industry; new product categories; macro trends; fashion; and futurism [Mason et al., 2015]. 


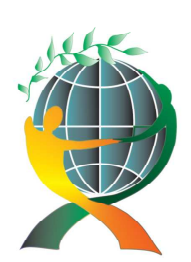

\author{
(online) $=$ ISSN $2285-3642$ \\ ISSN-L = $2285-3642$ \\ Journal of Economic Development, Environment and People \\ Volume 9, Issue 4, 2020 \\ URL: http://jedep.spiruharet.ro \\ e-mail: office jedep@spiruharet.ro
}

\title{
8.2.2 Causal-Comparative Research
}

The term causal-comparative appears to have originated in the early $20^{\text {th }}$ century. It always starts with observed effects and seeks to discover the antecedents of these effects [Good et al. 1935]. Here the researcher investigates how the independent variables are reflected by the dependent variables and involve cause and effect relationships between the variables. It attempts to determine reasons, or causes, for the existing condition [Gay, 1996]. It is also called "ex post facto or after the fact" research; as there is no manipulation of conditions due to the presumed cause has already occurred among groups of individuals before the study is initiated [Kerlinger \& Lee, 20003]. It is sometimes treated as a type of descriptive research since it describes conditions that already exist. It is regularly used in education studies when experimentation is not possible [McMillan \& Schumacher, 2009]. It discovers the possible causes and effects of personal characteristics by comparing individuals displaying the particular behavior pattern with individuals who do not display the behavior pattern [Borg \& Gall, 1989].

It provides the researcher with the opportunity to examine the interaction between independent variables and their influence on dependent variables. It is a form of study that tries to identify and determine the cause and effect of the relationship between two or more groups. It is less costly and timeconsuming to conduct, flexible by nature, and the researcher has little to no control over independent variables [Fraenkel \& Wallen, 1996].

There are two types of causal-comparative research: Retrospective and prospective causal-comparative research. In retrospective causal-comparative research a researcher starts to investigate a precise problem when the effects have previously happened and the researcher endeavors to determine if one variable might have prejudiced another variable. In prospective causal-comparative research, a researcher starts a study beginning with the causes and is resolute to evaluate the effects of a situation. The former is more common than the latter [Gay et al., 2006].

Some advantages of causal-comparative research are [Krathwohl, 1993; Fraenkel \& Wallen, 1996; McMillan \& Schumacher, 2009]: It shows a correlation where more rigorous experimentation is not possible, useful to avoid artificial in the research, and shows cause and effect relationships. Some disadvantages of causal-comparative research are [Krathwohl, 1993; Fraenkel \& Wallen, 1996; McMillan \& Schumacher, 2009]: It has lack of control for independent variable and randomizing subjects, may be regarded as too flexible, never certain if causative factor has been included or identified, and relationship between two factors does not establish cause and effect.

\subsubsection{Evaluation Research}

Evaluation research is the standard social research method and systematic measurement of the outcomes of a program to improve the quality of policy [Weiss, 1998]. As an analytical tool, it investigates a policy program to obtain all information pertinent to the assessment of its performance, both process and result. It serves as the basis for negotiating a study commission, project contract, and/or conducting the actual evaluation research study [Wollmann, 2003].

Evaluation research is appropriate whenever some social intervention occurs or is planned. It is the systematic assessment of the worth of time, money, effort and resources spent in order to achieve a goal. It enhances knowledge and decision-making and leads to practical applications. It is a form of applied research intended to have some real-world effect. To conduct evaluation research, researchers must be 


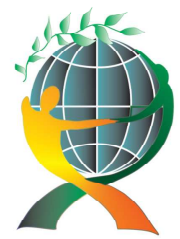

\author{
(online) $=$ ISSN $2285-3642$ \\ ISSN-L = $2285-3642$ \\ Journal of Economic Development, Environment and People \\ Volume 9, Issue 4, 2020 \\ URL: http://jedep.spiruharet.ro \\ e-mail: office jedep@spiruharet.ro
}

able to operate, observe, and measure. Recently evaluation research has become an increasingly popular and active research specialty, as reflected in textbooks, courses, and projects [Fischer et al., 2006].

It is important to enhance the success of activities, to see how well we are meeting objectives and goals, how the program benefits the community and to provide evidence of effectiveness, to build capacity increase funding, enhance skills, strengthen accountability [Levine et al., 1981]. There are two types of evaluation research [Wollmann, 2003]: an internal and external evaluation. Internal evaluation is carried out in-house by the operating agency itself and it takes place as self-evaluation. External evaluation is initiated or funded by outside sources. It is placed by institutions and actors that are outside and beyond administration.

\title{
8.2.4 Existing Data Research
}

The data were not created specifically by the researcher for the particular projects in which these will be used are known as existing data. In existing data research, the researcher uses data, documents, records, etc. that were in existence prior to any data collection on the part of the researcher [Cooke \& Theodore, 2013]. Existing data can be private or public. Over the last 20 years, a vast amount of data has been collected, compiled, archived, analyzed, and shared due to technological advances that are easily accessible for research [Doolan et al., 2017]. Day by day research with existing data is increasing all over the world. Low- and middle-income countries can use existing data if various research funding is limited [Smith et al. 2011; Cheng \& Phillips, 2014].

Some reliable sources of existing data are [Cheng \& Phillips, 2014; Doolan et al., 2017]: The World Health Organization (WHO) Global Health Observatory Data Repository, Behavioral Risk Factor Surveillance System, the Mayo Clinic, National Center for Education Statistics, Health Metrics and Evaluation at the University of Washington in the United States, Science and Engineering Statistics, Inter-university Consortium for Political and Social Research ((ICPSR), the United States Census Bureau, Centers for Disease Control and Prevention, California Health Interview Survey, National Health \& Nutrition Examination Survey, the United States Census, the Substance Abuse and Mental Health Services Administration, etc. These global originations provide dependable statistical data to advanced researchers.

The major advantages of existing data analysis are [Doolan \& Froelicher, 2009; Smith et al. 2011]: Since someone else has already collected the data, the researcher does not have to devote financial resources to the collection of data, consequently saves time. These are the cost-effectiveness and convenience these provide. When good existing data are available, researchers can gain access to and utilize high-quality reliable larger datasets for empirical research. These can accelerate the pace of research. These provide many opportunities for future research through replication, reanalysis, and reinterpretation of existing research. The limitations of existing data are [Smith et al. 2011; Johnston, 2014]: The secondary researcher did not participate in the data collection process and does not know exactly how it was conducted. If the existing data are affected by problems, research with these will be weaker, some cases will be meaningless. Potential errors may occur in selection and sampling with these data. Outdated existing data gave wrong information and provide a lack of fit between one set of data and another.

\subsubsection{Meta-Analysis}

The word "meta" comes from Greek to mean 'after' or 'beyond' and meta-analysis means an "analysis of analyses". A meta-analysis is a statistical analysis technique that combines the review results of quantitative studies with the precision of multiple scientific studies. It focuses on relations between study 


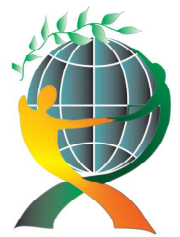

\author{
(online) $=$ ISSN $2285-3642$ \\ ISSN-L = 2285 - 3642 \\ Journal of Economic Development, Environment and People \\ Volume 9, Issue 4, 2020 \\ URL: http://jedep.spiruharet.ro \\ e-mail: office jedep@spiruharet.ro
}

features and outcomes. It is a sophisticated tool for decision-makers. It tries to determine how study features influence effect sizes [Glass, 1976; Borenstein et al., 2016].

The historical roots of meta-analysis can be traced back to $17^{\text {th }}$-century studies of astronomy. It is believed that the first meta-analysis study was conducted by Karl Pearson in 1904 when he attempted to synthesize the independent vaccine studies concerning typhoid [Littel et al., 2008]. Although meta-analysis is widely used in epidemiology and evidence-based medicine today, a meta-analysis of medical treatment was not published until 1955 [Plackett, 1958; Glass \& Smith, 1979]. The term "meta-analysis" was coined in 1976 by the statistician Gene V. Glass to describe the statistical combination of data from multiple studies [Glass, 1976]. After the 1980s, scientists began to develop meta-analysis [Cooper, 1998]

It provides a more objective appraisal of the evidence than a narrative review, and attempts to minimize bias by utilizing a methodological approach. It is based on mathematical and statistical rules [Egger et al., 1997; Lee, 2019]. It is not controlled over the timing of studies and the size of studies. It is not a hypothesistesting activity, and cannot reasonably be used to establish the reality of a reputed hazard or treatment [Charlton, 1996].

A fixed-effect meta-analysis assumes that there is one true intervention effect. The variation between studies is purely due to chance. A random-effects meta-analysis does not assume that there is one true effect [Hunter \& Schmidt, 2004].

Some strengths of meta-analysis are [Noble, 2006; Finckh \& Tramèr, 2008; Lee, 2019]: It overcomes small sample sizes of individual studies to detect the effects of interest and problems of traditional narrative reviews, increases statistical power, the generalizability of results and precision in estimating effects, and reduces the risk of false-negative results. It summarizes and quantifies results from individual studies, analyzes differences in the results of various studies, generates new hypotheses for further studies.

Some weaknesses of meta-analysis are [Noble, 2006; Finckh \& Tramèr, 2008; Lee, 2019]: It cannot overcome subjectivity. It includes only published studies, it may overestimate the actual magnitude of an effect, i.e., it may be publication bias. Summarizing large amounts of varying information using a single number is a controversial aspect of it. It only deals with main effects and potential disagreement with findings of randomized trials. If it includes low-quality studies, its results will be biassed and incorrect. It is homogenous in terms of populations, interventions, controls, and outcomes.

\title{
9. Characteristics of Quantitative Research
}

Characteristics of quantitative research are associated with positive paradigm. A quantitative research approach is characterized as being structured with predetermined variables, hypotheses and design [Bryman, 2012; Creswell, 2011]. It employs the traditional, the positivist, the experimental, or the empiricist method to enquire into an identified problem [Smith, 1975]. It is used to get answers in numerical form which makes relationship between an independent variable and a dependent variable within a large population. A numerical output is easy to read and understand, and it is easy to deduce a conclusion from the numerical outcome than a detailed result. Here the output is usually found in the form of graphs, range of numbers, statistical data, tables, and percentages, etc. to show trends, relationships, or differences among variables. In quantitative research data are collected by random sampling to ensure the accuracy, reliability and validity; consequently can avoid bias in the results. In quantitative research closeended questionnaires are used whose answers are more specific and right than the open-ended 


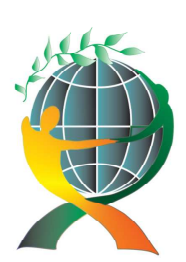

\author{
(online) = ISSN $2285-3642$ \\ ISSN-L = $2285-3642$ \\ Journal of Economic Development, Environment and People \\ Volume 9, Issue 4, 2020 \\ URL: http://jedep.spiruharet.ro \\ e-mail: office jedep@spiruharet.ro
}

questionnaires which are more detailed and scattered. Moreover, responses to the close-ended questionnaires are more reliable than the answers to open-ended questionnaires [Polit \& Beck, 2017].

Quantitative research has the following major characteristics [Brink \& Wood, 1998; Burns \& Grove, 2005]:

- All aspects of the study are carefully designed before quantitative research data collection.

- Data are collected in the form of numbers and statistics, often arranged in tables, charts, figures, percentage, or other non-textual forms. A numerical output is easy to read and understand, and deduce a meaningful conclusion than a detailed result.

- The data are usually collected using structured research modern instruments, such as questionnaires or computer software are used to collect numerical data.

- Statistical analysis is conducted to reduce and organize data, determine significant relationships and identify differences or similarities within and between different categories of data.

- Data gathering instruments contain items that solicit measurable characteristics of the population (e.g., age, the number of children, educational status, economic status, etc.).

- The results are based on larger sample sizes that are representative of the population.

- It is usually concise.

- It provides an accurate account of characteristics of particular individuals, situations, or groups.

- It emphasis on the procedures of comparing groups or relating factors about individuals or groups in experiments, correlational studies, and surveys.

- Standardized, pre-tested instruments guide data collection ensures the accuracy, quite reliability as participants of the research face close-ended questions, and high validity of data for repeated research study.

- Moreover, the outcome of quantitative research is easy to understand and explain.

\title{
10. Strengths of Quantitative Research
}

Quantitative research applies statistical tests, such as mean, median, and standard deviation, t-tests, multiple regression correlations (MRC), analysis of variances (ANOVAs), etc. Quantitative data are usually collected by surveys from large numbers of respondents randomly selected for inclusion. Sometimes secondary data, such as government statistics, census data, health system metrics, etc. are included in quantitative research. Some strengths of quantitative research are as follows [Walker, 2005; Atieno, 2009; Choy 2014]:

- Results from sample surveys can be generalized for entire populations.

- Relatively easy to analyze.

- Results can be aggregated and are comparable across population groups.

- Results can be broken down by socio-economic group for comparisons.

- Findings can be generalized if selection process is well-designed and sample is representative of study population.

- Reliability of data and findings provides powerful indicators to guide policy.

- Replicability publication of questionnaires and dataset permits scrutiny of findings.

- Transferability of dataset to other analysts means that analysis is not dependent on availability of an individual.

- Data can be very consistent, precise and reliable. 


\author{
(online) $=$ ISSN $2285-3642$ \\ ISSN-L = 2285 - 3642 \\ Journal of Economic Development, Environment and People \\ Volume 9, Issue 4, 2020 \\ URL: http://jedep.spiruharet.ro \\ e-mail: office jedep@spiruharet.ro
}

- Precise professional or disciplinary minimum standards exist for much survey work.

- Statistical methods mean that the analysis is often considered reliable.

- Appropriate for situations where systematic, standardized comparisons are needed.

\title{
11. Weaknesses of Quantitative Research
}

No doubt quantitative research is strong enough but has some weaknesses. Some weaknesses of quantitative research are as follows [Walker, 2005; Atieno, 2009; Choy 2014]:

- It sacrifices potentially useful information through process of aggregation.

- It provides useful data by placing households or events in discrete categories.

- It neglects intra-household processes and outcomes.

- It commonly under-reports on difficult issues, such as domestic violence and difficult to access individuals and households.

- Large amounts of the dataset are never used if the project is very expensive.

- Poorly trained enumerators can make mistakes and inadvertently influence responses.

- Enumerators may give false data.

- May give a false impression of homogeneity in a sample.

\section{Advantages of Quantitative Research}

In quantitative research statistical, computational, mathematical techniques, etc. are applied, i.e., it looks at measurable, numerical relationships to obtain the accurate result. It is often seen as more accurate than qualitative research, which focuses on gathering non-numerical data [Bryman, 2012; Goertz \& Mahoney, 2012]. In quantitative research the statistical package for social science (SPSS) are used and data are calculated and conducted by computer, it saved time and resources. Indeed it is scientific in nature and research findings are more reliable [Connolly, 2007]. Some advantages of quantitative research are as follows [Walker, 2005; Atieno, 2009; Choy 2014]:

- It requires careful experimental design and the ability for anyone to replicate both the test and the results.

- It allows the researcher to measure and analyze data.

- It strives to control for bias so that facts, instances, and phenomena can be understood in an objective way.

- It allows for statistical comparison between various groups.

- The data is considered quantifiable and usually generalizable to a larger population.

- Test hypotheses are used in experiments because of its ability to measure data using statistics.

- As statistical tests are appropriately use, less error occur during the research.

- Relationship between an independent and dependent variable is studied in detail, which is advantageous because the researcher is more objective about the findings of the research.

- It emphasizes large samples that can provide an overview of an area that can reveal patterns, inconsistencies, and so forth.

- It measures level of occurrence, actions, trends, etc.

- It can provide a clear, quantitative measure to be used for grants and proposals. 


\author{
(online) $=$ ISSN $2285-3642$ \\ ISSN-L = 2285-3642 \\ Journal of Economic Development, Environment and People \\ Volume 9, Issue 4, 2020 \\ URL: http://jedep.spiruharet.ro \\ e-mail: office jedep@spiruharet.ro
}

- It has precision, is definitive and standardized.

- It can be used when large quantities of data need to be collected.

- It indicates the extensiveness of attitudes held by people.

\title{
13. Disadvantages of Quantitative Research
}

Qualitative research is very popular and strong but; it has also some disadvantages. It strictly follows statistical relationships that overlook broader themes and relationships. As a result, it has a risk of missing important information of research [Bryman, 2012; Goertz \& Mahoney, 2012]. Some disadvantages of quantitative research are as follows [Atieno, 2009; Creswell, 2011; Choy 2014]:

- Results need to be calculated using Excel, Access, or SPSS, which may not always be accessible to a country program.

- It can be limited in its pursuit of concrete, statistical relationships.

- The bias occurs earlier in the process of quantitative research.

- The context of the study or experiment is ignored.

- It is difficult to understand context of a phenomenon.

- Related secondary data is sometimes not available.

- Data may not be robust enough to explain complex issues.

- It is time consuming. The larger the sample, the more time it takes to analyze the data and analyze results.

- It ignores a very important human element.

\section{Quantitative Evaluation}

Quantitative evaluation criteria comprised of the combination of validity, reliability and generalizability. Validity is confirmed if results from a randomized sample with the assurance that conflict of interest have been minimized. Reliability is verified with an adequate sample size so that conclusions can be drawn with precision and accuracy [Mohajan, 2017]. Generalizability is of necessary as, it allows the results to be applied to the population at large [Morris \& Burkett, 2011].

\section{Ethical Reflections}

Ethics pertain to morally good or correct practice and avoid any harm that may emanate during the study. Ethics are essential in any research [Lillemoen \& Pedersen, 2013]. Strength and integrity are useful for a successful quantitative research. These depend on how the researchers design their researches. Ethic is an important characteristic in any research, which is about professional regulations and codes of conduct that guide the researcher in his dealings with participants [Denzin \& Lincoln, 2005].

In any research respondents are assured that their names and the names of their organizations would be dealt with in the strictest confidence. Their trust would not be exploited for personal gain or benefit, by deceiving or betraying them in the research [Lubbe, 2003]. Researchers must "do no harm" as they collect data from someone and report findings to someone [Berg \& Howard, 2012]. An ethical challenge happens where there are doubts, uncertainties or disagreements about what is morally good or correct practice and avoids any harm [Lillemoen \& Pedersen, 2013].

Sometimes researchers do not follow the ethical characteristics during this type of research. For example, during World War II, Nazi scientists conducted some experiments, such as immersing people in ice 


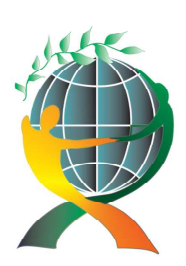

\author{
(online) = ISSN $2285-3642$ \\ ISSN-L = $2285-3642$ \\ Journal of Economic Development, Environment and People \\ Volume 9, Issue 4, 2020 \\ URL: http://jedep.spiruharet.ro \\ e-mail: office jedep@spiruharet.ro
}

water to know how long it would take them to freeze into death. They also injected prisoners with newly developed drugs to know their effectiveness; consequently many died in the process, which are unethical and inhumane [Christensen, 1988].

According to William Lawrence Neuman "Ethics begins and ends with you, the researcher". Some general ethical issues in research that result in some prohibitions are [Neuman, 2012]:

- never cause unnecessary or irreversible harm to participants,

- secure prior voluntary consent when possible and never unnecessarily humiliate, and

- degrade, or release harmful information about specific individuals that was collected for research purposes.

In this study we have tried to maintain ethics strictly. In the theoretical analysis we have given proper references in the research. We have maintained the ethical formalities throughout the study [Mohajan, 2018b].

\title{
16. Conclusions and Recommendations
}

In this study we have tried to discuss the components of quantitative research methodology in a systematic and logical order. We observe that this type of research is highly structured, and the results are determined numerically or statistically. Researchers prefer quantitative research for its creative characteristics and strengths. Worldwide it is one of the most used approaches to conduct natural and social science researches.

In the study we have observe that the quantitative research methodology is founded on the scientific method. It uses experimental and observed measurements to develop theories and advance knowledge in the research area. In this type of research the variables are clearly defined and results seem very accurate, as the results are obtained by mathematical formulae and statistical analyses. We have discussed the historical background, steps and types of quantitative research. We have also briefly overview the characteristics, strengths, weaknesses, advantages, and disadvantages, ethical reflections of this type of research.

A researcher must be more conscious during data collection and interpretation to avoid bias in quantitative research. We confirm that in future, quantitative researchers must contribute more knowledge in their true and original researches. We hope that this review paper will help new researchers to write qualitative research articles accurately and efficiently.

\section{References}

[1] Adams, J., Khan, H. T. A., Raeside, R., \& White, D. (2007). Research Methods for Graduate Business and Social Science Students. Sage Publications Ltd., London.

[2] Adler, P. A., \& Adler, P. (1994). Observational Techniques. In N. K. Denzin \& Y. S. Lincoln (Eds.), Handbook of Qualitative Research, pp. 377-392. Thousand Oaks, CA: Sage Publications.

[3] Aggarwal, Y. P. (2008). Statistics of Education. (2 ${ }^{\text {nd }}$ Ed.) Delhi: Sterling.

[4] Aina, J. K. (2017). Developing a Constructivist Model for Effective Physics Learning. International Journal of Trend in Scientific Research and Development, 1(4), 59-67.

[5] Aldrick, J. (1995). Correlation Genuine and Spurious in Pearson and Yule. Statistical Science, 10(4), 364-376. 


\author{
(online) $=$ ISSN $2285-3642$ \\ ISSN-L = $2285-3642$ \\ Journal of Economic Development, Environment and People \\ Volume 9, Issue 4, 2020 \\ URL: http://jedep.spiruharet.ro \\ e-mail: office jedep@spiruharet.ro
}

[6] Alexander, J. C. (1995). Fin De Siecle Social Theory: Relativism, Reductionism and the Problem of Reason. London; Verso.

[7] Anderson, G., \& Arsenault, N. (1998). Fundamentals of Educational Research. Routledge.

[8] Andreß, H.-J. (2017). The Need for and Use of Panel Data. IZA World of Labor, Germany.

[9] Angrosino, M. V. (2005). Recontextualizing Observation: Ethnography, Pedagogy, and the Prospects for a Progressive Political Agenda. In N. Denzin \& Y. Lincoln (Eds.), The Sage Handbook of Qualitative Research ( $3^{\text {rd }}$ Ed.), pp. 729-745. Thousand Oaks: Sage.

[10] Ary, D., Jacobs, L. C., \& Razavieh, A. (2010). Introduction to Research in Education (8 ${ }^{\text {th }}$ Ed.). Wadsworth: Cengage Learning.

[11] Asamoah, K. M. (2014). Re-examination of the Limitations Associated with Correlational Research. Journal of Educational Research and Reviews, 2(4), 45-52.

[12] Atieno, O. (2009). An Analysis of the Strengths and Limitation of Qualitative and Quantitative Research Paradigms. Problems of Education in the $21^{\text {st }}$ Century, 13, 13-18.

[13] Babbie, E. (2001). The Practice of Social Research $\left(9^{\text {th }}\right.$ Ed.). Wadsworth Thomson, Belmont.

[14] Baker, L. M. (2006). Observation: A Complex Research Method. Library Trends, 55(1), 171-189.

[15] Baltes, P. B., \& Nesselroade, J. R. (1979). History and Rationale of Longitudinal Research. In J. R. Nesselroade \& P. B. Baltes (Eds.), Longitudinal Research in the Study of Behavior and Development, pp. 1-39. New York: Academic Press.

[16] Berg, B. L., \& Howard, L. (2012). Qualitative Research Methods for the Social Sciences (8 ${ }^{\text {th }}$ Ed.). USA: Pearson Educational Inc.

[17] Best, J. W. (1981). Research in Education (4 ${ }^{\text {th }}$ Ed.). Prentice Hall of India Pvt. Ltd., New Delhi.

[18] Best, J. W., \& Kahn, J. V. (2007). Research in Education. Prentice Hall of India Private, New Delhi.

[19] Bethlehem, J. (2009). Applied Survey Method: A Statistical Perspective. Hoboken: John Wiley \& Sons, Inc., Publications.

[20] Blessing, L. T. M., Chakrabarti, A., \& Wallace, K. M. (1998). An Overview of Descriptive Studies in Relation to a General Design Research Methodology. In E. Frankenberger, P. Badke-Schaub \& H. Birkhofer (Eds.), Designers: The Key to Successful product Development. Berlin: Springer Verlag.

[21] Bogin, B. (1999). Patterns of Human Growth (2 ${ }^{\text {nd }}$ Ed.). Cambridge: Cambridge University Press.

[22] Borbasi, S., \& Jackson, D. (2012). Navigating the Maze of Research. Chatswood, Sydney: Mosby Elsevier.

[23] Borenstein, M., Hedges, L. V., Higgins, J. P. T., \& Rothstein, H. (2016). Introduction to Meta-Analysis. Chichester: John Wiley \& Sons, Ltd.

[24] Borg, W., \& Gall, M. D. (1989). Educational Research: An Introduction (5 ${ }^{\text {th }}$ Ed.). New York: Longman.

[25] Brink, P. J., \& Wood, M. J. (1998). Advanced Designs in Nursing Research (2 ${ }^{\text {nd }}$ Ed.). Thousand Oaks: Sage.

[26] Bryman, A. (2012). Social Research Methods (4 ${ }^{\text {th }}$ Ed.). New York: Oxford University Press.

[27] Buck, N. (2008). Introducing Panel Surveys: The BHPS in Praise of Panel Surveys. Essex: ISER.

[28] Buffon, G. (1837). A Sur L'accroissement Successif des Enfants; Gueneau de Montbeillard Mesure de 1759 a 1776. Oeuvres Completes. Paris: Furne et Cie. 


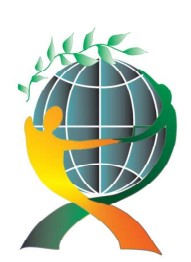

\author{
(online) = ISSN $2285-3642$ \\ ISSN-L = $2285-3642$ \\ Journal of Economic Development, Environment and People \\ Volume 9, Issue 4, 2020 \\ URL: http://jedep.spiruharet.ro \\ e-mail: office jedep@spiruharet.ro
}

[29] Burns, N., \& Grove, S. K. (2005). The Practice of Nursing Research, Conduct, Critique, and Utilization (5 ${ }^{\text {th }}$ Ed.). St Louis: Elsevier.

[30] Campbell, D. T. (1957). Factors Relevant to the Validity of Experiments in Social Settings. Psychological Bulletin, 54, 297-312.

[31] Campbell, D. T., \& Stanley, J. C. (1963). Experimental and Quasi-Experimental Designs for Research. Chicago: Rand McNally College Publishing Co.

[32] Carlson, N. R., Miller, H. L. Jr., Heth, D. S., Donahoe, J. W., Martin, G. N. (2009). Psychology: the Science of Behavior ( $7^{\text {th }}$ Ed.). Boston, Massachusetts: Allyn \& Bacon.

[33] Caruana, E. J., Roman, M., Hernández-Sánchez, J., \& Solli, P. (2015). Longitudinal studies. Journal of Thoracic Disease, 7(11), E537-E540.

[34] Casadevall, A., \& Fang, F. C. (2008). Descriptive Science. Infection and Immunity, 76(9), 3835-3836.

[35] Charlton, B. G. (1996). The USES and Abuses of Meta-Analysis. Family Practice, 13(4), 397-401.

[36] Chen, C. C. (2011). Quantitative Methodology: Appropriate use in Research for Blind Baseball Ergonomics and Safety Design. Journal of Human Resource and Adult Learning, 7(1), 1-6.

[37] Cheng, H. G., \& Phillips, M. R. (2014). Secondary Analysis of Existing Data: Opportunities and Implementation. Shanghai Arch Psychiatry, 26(6), 371-375.

[38] Choy, L. (2014). The Strengths and Weaknesses of Research Methodology: Comparison and Complimentary Between Qualitative and Quantitative Approaches. IOSR Journal of Humanities and Social Science, 19(4), 99-104.

[39] Christensen, L. (1988). Experimental Methodology. Boston: Allyn and Bacon Inc.

[40] Cohen, L., Manion, L., \& Morrison, K. (2000). Research Methods in Education (5 ${ }^{\text {th }}$ Ed.). London: Routledge.

[41] Collis, I., \& Hussey, R. (2009). Business Research: A Practical Guide for Undergraduate and Postgraduate Students ( $3^{\text {rd }}$ Ed.). New York: Palgrave McMillan.

[42] Connolly, P. (2007). Qualitative Data Analysis in Education: A Critical Introduction Using SPSS. London: Routledge.

[43] Cooke, C. R., \& Theodore, J. I. (2013). Using Existing Data to Address Important Clinical Questions in Critical Care. Critical Care Medicine, 41(3), 886-896.

[44] Cooper, C. R., \& Schindler, P. S. (2008). Business Research Methods (10 ${ }^{\text {th }}$ Ed.). Boston: McGraw-Hill.

[45] Cooper, H. (1998). Synthesizing Research. Thousand Oaks, CA: Sage.

[46] Creswell, J. W. (2011). Research Design: Qualitative, Quantitative and Mixed Method Approaches (4 ${ }^{\text {th }}$ Ed.). Los Angeles: Sage Publications.

[47] Daniel, E. (2016). The Usefulness of Qualitative and Quantitative Approaches and Methods in Researching Problem-Solving Ability in Science. Journal of Education and Practice, 7(15), 91-100.

[48] de Leeuw, E. D., Hox, J. J., \& Dillman, Don A. (Eds.) (2008). International Handbook of Survey Methodology. European Association of Methodology (EAM) Book Series. http://www.eam-online.org

[49] Denzin, N. K., \& Lincoln,Y. S. (2005). The SAGE Handbook of Qualitative Research (3 ${ }^{\text {rd }}$ Ed.). California: SAGE Publication.

[50] Disman, A. M., \& Barliana, S. M. (2017). The Use of Quantitative Research Method and Statistical Data Analysis in 


\author{
(online) $=$ ISSN $2285-3642$ \\ ISSN-L = $2285-3642$ \\ Journal of Economic Development, Environment and People \\ Volume 9, Issue 4, 2020 \\ URL: http://jedep.spiruharet.ro \\ e-mail: office jedep@spiruharet.ro
}

Dissertation: An Evaluation Study. International Journal of Education, 10(1), 46-52.

[51] Doolan, D. M., \& Froelicher, E. S. (2009). Using an Existing Data Set to Answer New Research Questions: A Methodological Review. International Journal of Research and Theory for Nursing Practice, 23(3), 203-215.

[52] Doolan, D. M., Winters, J., \& Nouredini, S. (2017). Answering Research Questions Using an Existing Data Set. Medical Research Archives, 5(9), 1-14.

[53] Duffy, M. E. (1985). Designing Nursing Research the Qualitative-Quantitative Debate. Journal of Advanced Nursing, 10(3), 225-232.

[54] Duncan, G. J., Juster, F. T., \& Morgan, J. N. (1987). The Role of Panel Studies in Research on Economic Behavior. Transportation Research, 21A(4/5), 249-263.

[55] Egger, M., Smith, G. D., \& Phillips, A. N. (1997). Meta-Analysis: Principles and Procedures. British Medical Journal (BMJ), 315 (7121), 1533-1537.

[56] Ertem-Eray, T. (2019). The Status of Digital Culture in Public Relations Research in Turkey: An Analysis of Published Articles in 1999-2017. Handbook of Research on Examining Cultural Policies through Digital Communication.

[57] Euser, A. M., Zoccali, C., Jager, K. J., Dekker, F. W. (2009). Cohort Studies: Prospective Versus Retrospective. Nephron Clinical Practice, 113, c214-c217.

[58] Finckh, A., \& Tramèr, M. R. (2008). Primer: Strengths and Weaknesses of Meta-Analysis. Nature Clinical Practice Rheumatolog, 4(3), 146-152.

[59] Fischer, F., Miller, G. J., \& Sidney, M. S. (2006). Handbook of Public Policy Analysis: Theory, Methods. and Politics. New York: Marcel Dekker.

[60] Foster, P. (2006). Observational Research ( $2^{\text {nd }}$ Ed.). In Roger Sapsford \& Victor Jupp (Eds.), Data Collection and Analysis. Sage Publications Inc.

[61] Fox, N. J. (2008). Post-positivism. In L. M. Given (Ed.). The SAGE Encyclopedia of Qualitative Research Methods. London: Sage.

[62] Fraenkel, J. R., \& Wallen, N. E. (1996). How to Design and Evaluate Research in Education (3 ${ }^{\text {rd }}$ Ed.). New York: McGraw-Hill.

[63] Fry, M., Curtis, K., Considine, J., \& Shaban, R. Z. (2017). Using Observation to Collect Data in Emergency Research. Australasian Emergency Nursing Journal, 20, 25-30.

[64] Garbett, D. (2011). Constructivism Deconstructed in Science Teacher Education. Australian Journal of Teacher Education, 36(6), 36-49.

[65] Gay, L. R. (1996). Educational Research: Competencies for Analysis and Application (5 ${ }^{\text {th }}$ Ed.). Englewood Cliffs, NJ: Prentice-Hall.

[66] Gay, L. R., Mills, G., \& Airasian, P. (2006). Educational Research: Competencies for Analysis and Applications. New Jersey: Pearson Education, Inc.

[67] Given, L. M. (2008). The Sage Encyclopedia of Qualitative Research Methods. Los Angeles, Calif.: Sage Publications.

[68] Glasow, P. A. (2005). Fundamentals of Survey Research Methodology. MITRE Product, Washington C3 Center.

[69] Glass, G. V. (1976). Primary, Secondary, and Meta-Analysis of Research. Educational Researcher, 5(10), 3-8.

[70] Glass, G. V., \& Hopkins, K. D. (1984). Statistical Methods in Education and Psychology. Upper Saddle River, NJ: 


\author{
(online) $=$ ISSN $2285-3642$ \\ ISSN-L = 2285-3642 \\ Journal of Economic Development, Environment and People \\ Volume 9, Issue 4, 2020 \\ URL: http://jedep.spiruharet.ro \\ e-mail: office jedep@spiruharet.ro
}

Prentice-Hall.

[71] Glass, G. V., \& Smith, M. L. (1979). Meta-Analysis of Research on Class Size and Achievement. Educational Evaluation and Policy Analysis, 1(1), 2-16.

[72] Goertz, G., \& Mahoney, J. (2012). A Tale of Two Cultures: Qualitative and Quantitative Research in the Social Sciences. Princeton University Press.

[73] Good, C. V., Barr, A. S., \& Scates, D. E. (1935). The Methodology of Educational Research. NewYork: AppletonCentury-Crofts.

[74] Gomes, N. P., Cohen, S. A., \& Flores, A. M. M. (2018). Trend Studies: An Approach for Analyzing and Managing Culture. ModaPalavra e-Periódico, 11(22), 82-112.

[75] Gorman, G. E., \& Clayton, P. (2005). Qualitative Research for the Information Professional (2 ${ }^{\text {nd }}$ Ed.). London: Facet.

[76] Gravlee, C. C., Kennedy, D. P., Godoy, R., \& Leonard, W. R. (2009). Methods For Collecting Panel Data: What Can Cultural Anthropology Learn from Other Disciplines? Journal of Anthropological Research, 65, 453-483.

[77] Greaves, L. M. (2017). An Investigation into the Feasibility of an Online National Probability Panel Study in New Zealand. Compass Research Centre, University of Auckland, New Zealand.

[78] Grimes, D. A., \& Schulz, K. F. (2002). Cohort Studies: Marching Towards Outcomes. The Lancet, 359, $341-345$.

[79] Grinnell, R. Jr. (Eds.) (1993). Social Work Research and Evaluation (4 ${ }^{\text {th }}$ Ed.). Itasca, IL, F.E. Peacock.

[80] Hall, L. H. (2018). A Quantitative Correlational Study between Transformational Leadership Behavior and Job Satisfaction among California Card Room Casino Employees. PhD Dissertation. Brandman University, Irvine, California.

[81] Harris, A. D., Bradham, D. D., Baumgarten, M., Zuckerman, I. H., Fink, J. C., Perencevich, E. N. (2004). The Use and Interpretation of Quasi-Experimental Studies in Infectious Diseases. Clinical Infectious Diseases, 38, $1586-1591$.

[82] Hulley, S. B., Cummings, S. R., Browner, W. S., Grady, D., Hearst, N., \& Newman, R. B., (Eds.) (2001). Designing Clinical Research: An Epidemiologic Approach ( $2^{\text {nd }}$ Ed.). Baltimore: Lippincott Williams and Wilkins.

[83] Hunter, J. E., \& Schmidt, F. L. (2004). Methods of Meta-Analysis: Correcting Error and Bias in Research Findings $\left(2^{\text {nd }}\right.$ Ed.). Sage Publications, Thousand Oaks, London.

[84] Hunter, L., \& Leahey, E. (2008). Collaborative Research in Sociology: Trends and Contributing Factors. The American Sociologist, 39(4), 290-306.

[85] Johnson, B., \& Turner, L. A. (2003). Data Collection Strategies in Mixed Methods Research. In A. Tashakkori \& C. Teddie (Eds.). Handbook of Mixed Methods in Social and Behavioral Research, pp. 297-319. Thousand Oaks, CA: Sage.

[86] Johnston, M. P. (2014). Secondary Data Analysis: A Method of Which the Time Has Come. Qualitative and Quantitative Methods in Libraries (QQML), 3, 619-626.

[87] Kerlinger, F. N., \& Lee, H. B. (Eds.) (2000). Foundations of Behavioral Research (4 ${ }^{\text {th }}$ Ed.). Orlando, FL: Harcourt College Publishers.

[88] Kincheloe, L. J., \& Tobin, K. (2009). The Much Exaggerated Death of Positivism. Cultural Study of Science 


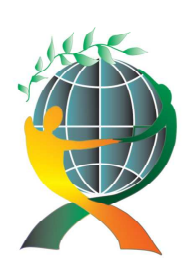

\author{
(online) = ISSN $2285-3642$ \\ ISSN-L = 2285 - 3642 \\ Journal of Economic Development, Environment and People \\ Volume 9, Issue 4, 2020 \\ URL: http://jedep.spiruharet.ro \\ e-mail: office jedep@spiruharet.ro
}

Education, 4, 513-528.

[89] Koh, E. T., \& Owen, W. L. (2000). Introduction to Nutrition and Health Research. Boston: Kluwer Academic.

[90] Kothari, C. R. (2008). Research Methodology: Methods and Techniques (2 ${ }^{\text {nd }}$ Ed.). New Delhi: New Age International (P) Ltd.

[91] Krathwohl, D. R. (1993). Methods of Educational and Social Science Research: An Integrated Approach. Longman/Addison Wesley Longman.

[92] Kumar, R. (2011). Research Methodology: A Step-by-Step Guide for Beginners. Sage Publications Ltd., London.

[93] Lee, Y. H. (2019). Strengths and Limitations of Meta-Analysis. Korean Journal of Medicine, 94(5), 391-395.

[94] Leedy, P. D. (1993). Practical Research: Planning and Design. New Jersey: Prentice-Hall.

[95] Leedy, P. D. \& Ormrod, J. (2001). Practical Research: Planning and Design ( ${ }^{\text {th }}$ Ed.). Upper Saddle River, NJ: Merrill Prentice Hall. Thousand Oaks: Sage Publications.

[96] Letourneau, N., \& Allen, M. (1999). Post-positivistic Critical Multiplism: A Beginning Dialogue. The Journal of Advanced Nursing, 30, 623-630.

[97] Levin, K. A. (2006). Study Design III: Cross-Sectional Studies. Evidence-Based Dentistry, 7(1), 24-25.

[98] Levine, R. A., Solomon, M. A., Hellstern, G., \& Wollmann, H. (Eds.) (1981). Evaluation Research and Practice. Comparative and International Perspectives, Beverly Hills/London: Sage.

[99] Liddell, F. D. K. (1988). The Development of Cohort Studies in Epidemiology: A Review. Journal of Clinical Epidemiology, 41(12), 1217-1237.

[100] Lillemoen, L., \& Pedersen, R. (2013). Ethical Challenges and How to Develop Ethics Support in Primary Health Care. Nursing Ethics, 20(1), 96-108.

[101] Lincoln, Y. S., \& Guba, E. G. (1985). Naturalistic Inquiry. Beverly Hills, CA: Sage Publications.

[102] Littel, H. J., Corcoran, J., \& Pillai, V. (2008). Systematic Reviews and Meta-Analysis. New York: Oxford University Press.

[103] Loeb, S., Dynarski, S., McFarland, D., Morris, P., Reardon, S., \& Reber, S. (2017). Descriptive Analysis in Education: A Guide for Researchers. Washington, DC: U.S. Department of Education, Institute of Education Sciences, National Center for Education Evaluation and Regional Assistance.

[104] Lubbe, S. (2003). Development of a Case Study Methodology in the Information Technology (IT) Field in South Africa: A Step-by-Step Approach. SA Journal of Information Management, 5(4), a380. https://doi.org/10.4102/sajim.v5i4.380

[105] Lynn, P. (2009). Methodology of Longitudinal Surveys. Chichester: John Wiley \& Sons Ltd., UK.

[106] Mathers, N., Fox, N., \& Hunn, A. (2009). Surveys and Questionnaires. The NIHR RDS for the East Midlands/Yorkshire \& the Humber.

[107] Mathiyazhagan, T. \& Nandan, D. (2010). Survey Research Method. Media Mimansa, 4(1), 34-45.

[108] McClosky, H. (1969). Political Inquiry: The Native and Uses of Survey Research. Macmillan, New York.

[109] McMillan, J. H., \& Schumacher, S. (2009). Research in Education: Pearson Education.

[110] Mildner, V. (2019). The SAGE Encyclopedia of Human Communication Sciences and Disorders. In Jack S. Damico \& Martin J. Ball (Eds.). Experimental Research, pp. 728-732. Thousand Oaks, SAGE Publications, Inc. 


\author{
(online) = ISSN $2285-3642$ \\ ISSN-L = $2285-3642$ \\ Journal of Economic Development, Environment and People \\ Volume 9, Issue 4, 2020 \\ URL: http://jedep.spiruharet.ro \\ e-mail: office jedep@spiruharet.ro
}

[111] Mohajan, H. K. (2017). Two Criteria for Good Measurements in Research: Validity and Reliability. Annals of Spiru Haret University Economic Series, 17(3), 58-82.

[112] Mohajan, H. K. (2018a). Qualitative Research Methodology in Social Sciences and Theoretical Economics. Journal of Economic Development, Environment and People, 7(1), 23-48.

[113] Mohajan, H. K. (2018b). Aspects of Mathematical Economics, Social Choice and Game Theory. PhD Dissertation, Jamal Nazrul Islam Research Centre for Mathematical and Physical Sciences, University of Chittagong, Chittagong, Bangladesh.

[114] Morris, E., \& Burkett, K. (2011). Mixed Methodologies: A New Research Paradigm or Enhanced Quantitative Paradigm. Online Journal of Cultural Competence in Nursing and Healthcare, 1(1), 27-36.

[115] Mueller, M., D’Áddario, M., Egger, M., Cevallos, M., Dekkers, O., Mugglin, C., \& Scott, P. (2018). Methods to Systematically Review and Meta-Analyse Observational Studies: A Systematic Scoping Review of Recommendations. BMC Medical Research Methodology, 18(1), 44.

[116] Murphy, E, \& Dingwall, R. (2007). Informed Consent, Anticipatory Regulation and Ethnographic Practice. Social Science \& Medicine, 65(11), 2223-2234.

[117] National Institutes of Health (NIH) (1997). Changes in Cigarette-Related Disease Risks and their Implication for Prevention and Control. Bethesda, MD: US Department of Health and Human Services, National Institutes of Health, National Cancer Institute. NIH Publication No. 97-4213.

[118] Neuman, W. L. (2012). Basics of Social Research ( $3^{\text {rd }}$ Ed.). Boston: Pearson/Allyn and Bacon.

[119] Noble, J. H. Jr. (2006). Meta-Analysis: Methods, Strengths, Weaknesses, and Political Uses. Journal of Laboratory and Clinical Medicine, 147(1), 7-20.

[120] Nola, R., \& Irzik, G. (2006). Philosophy, Science, Education and Culture. Springer Science \& Business Media.

[121] Nunan, D. (1992). Research Methods in Language Learning. Cambridge University Press.

[122] OECD (2002). Frascati Manual: Proposed Standard Practice for Surveys on Research and Experimental Development ( $6^{\text {th }}$ Ed.). OECD Publication service, Paris Cedex, France.

[123] Ojo, S. O. (2003). Productivity and Technical Efficiency of Poultry Egg Production in Nigeria. International Journal of Poultry Science, 2, 459-464.

[124] Park, Y. S., Konge, L., \& Artino, T. (2020). The Positivism Paradigm of Research. Academic Medicine, 95, 690694.

[125] Phillips, D. C., \& Burbules, N. C. (2000). Postpositivism and Educational Research. Lanham, MD: Rowman \& Littlefield.

[126] Pinsonneault, A., \& Kraemer, K. L. (1993). Survey Research Methodology in Management Information Systems: An Assessment. Journal of Management Information Systems, 10, 75-105.

[127] Plackett, R. L. (1958). Studies in the History of Probability and Statistics: The Principle of the Arithmetic Mean. Biometrika, 45(1-2), 133.

[128] Polit, D. F., \& Beck, C. T. (2017). Nursing Research: Generating and Assessing Evidence for Nursing Practice $\left(10^{\text {th }}\right.$ Ed.). Wolters Kluwer Health, Philadelphia. 


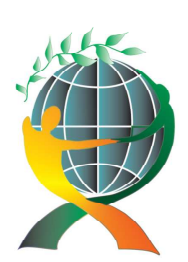

\author{
(online) = ISSN $2285-3642$ \\ ISSN-L = $2285-3642$ \\ Journal of Economic Development, Environment and People \\ Volume 9, Issue 4, 2020 \\ URL: http://jedep.spiruharet.ro \\ e-mail: office jedep@spiruharet.ro
}

[129] Polit, D. F., \& Hungler, B. P. (2013). Essentials of Nursing Research: Methods, Appraisal, and Utilization (8 ${ }^{\text {th }}$ Ed.). Philadelphia: Wolters Kluwer/Lippincott Williams and Wilkins.

[130] Popper, K. (1963). Conjectures and Refutations: The Growth of Scientific Knowledge. London; Routledge.

[131] Popper, K. (2005). The Logic of Scientific Discovery. Abingdon, UK: Routledge.

[132] Powell, R. R. (2006). Evaluation Research: An Overview. Library Trends, 55 (1), 102-120.

[133] Queirós, A., Faria, D., \& Almeida, F. (2017). Strengths and Limitations of Qualitative and Quantitative Research Methods. European Journal of Education Studies, 3(9), 369-387.

[134] Rahman, S. (2017). The Advantages and Disadvantages of Using Qualitative and Quantitative Approaches and Methods in Language "Testing and Assessment" Research: A Literature Review. Journal of Education and Learning, 6(1), 102-112.

[135] Rajulton, F. (2001). The Fundamentals of Longitudinal Research: An Overview. Canadian Studies in Population, 28(2), 169-185.

[136] Rarner, L. (1989). Quantitative Versus Qualitative Research? Journal of Obstetric, Gynecologic and Neonatal Nursing, 18, 7-8.

[137] Rech, S. R. (2016). A Qualitative Research on Trends Studies. In CIMODE $20163^{\text {rd }}$ International Fashion and Design Congress, Buenos Aires, Argentina.

[138] Robson, C. (2002). Real World Research: A Resource for Social Scientists and Practitioner-Researchers (2 ${ }^{\text {nd }}$ Ed.). Malden: Blackwell.

[139] Ross, D. A., \& Vaughan, J. P. (1986). Health Interview Surveys in Developing Countries: A Methodological Review. Studies in Family Planning, 17(2), 78-94.

[140] Ruspini, E. (2002). Introduction to Longitudinal Research. New York: Routledge.

[141] Salant, P., \& Dillman, D. A. (1994). How to Conduct Your Own Survey. New York: John Wiley and Sons.

[142] Samet, J. M., \& Munoz, A. (1998). Evolution of the Cohort Study. Epidemiologic Reviews, 20(1), 1-14.

[143] Samuel, M., \& Okey, L. E. (2015). The Relevance and Significance of Correlation in Social Science Research. International Journal of Sociology and Anthropology Research, 1(3), 22-28.

[144] Sekaran, U. (2000). Research Methods for Business a Skill Business Approach. John Wiley \& Sons, New York.

[145] Setia, M. S. (2016). Methodology Series Module 3: Cross-sectional Studies. Indian Journal of Dermatology, 61(3), 261-264.

[146] Smith, A. K., Ayanian, J. Z., Covinsky, K. E., Landon, B. E., McCarthy, E. P., Wee, C. C., \& Steinman, M. A. (2011). Conducting High-Value Secondary Dataset Analysis: An Introductory Guide and Resources. Journal of General Internal Medicine, 28(8), 920-929.

[147] Smith, H. W. (1975). Strategies of Social Research: The Methodological Imagination. Englewood Cliffs, NJ: Prentice Hall.

[148] Sukamolson, S. (2007). Fundamentals of Quantitative Research. Language Institute, Chulalongkorn University, 1-20.

[149] Swanson, R. A., \& Holton, E. F. III. (Eds.) (2005). Research in Organizations: Foundations and Methods of Inquiry. SanFrancisco: Berrett-Koehler. 


\author{
(online) = ISSN $2285-3642$ \\ ISSN-L = 2285 - 3642 \\ Journal of Economic Development, Environment and People \\ Volume 9, Issue 4, 2020 \\ URL: http://jedep.spiruharet.ro \\ e-mail: office jedep@spiruharet.ro
}

[150] Tuma, N., \& Hannan, M. (1984). Social Dynamics: Models and Methods. New York: Academic Press.

[151] Vejlgaard, H. (2008). Anatomy of a Trend. New York: McGraw-Hill.

[152] Venkatesh, A., \& Vitalari, N. P. (1991). Longitudinal Surveys in Information Systems Research: An Examination of Issues, Methods, and Applications. In Ken Kramer (Ed.), The Information Systems Challenge: Survey Research Methods. Harvard University Press, pp. 115-144, Harvard University Press.

[153] Walker, W. (2005). The Strengths and Weaknesses of Research Designs Involving Quantitative Measures. Journal of Research in Nursing, 10(5), 571-582.

[154] Wang, M., Beal, D. J, Chan, D., Newman, D. A. Vancouver, J. B., \& Vandenberg, R. J. (2017). Longitudinal Research: A Panel Discussion on Conceptual Issues, Research Design, and Statistical Techniques. Work, Aging and Retirement, 3(1), 1-24.

[155] Warfield, D. (2013). IS/IT Research: A Research Methodologies Review. Journal of Theoretical and Applied Information Technology, 3(1), 28-35.

[156] Weiss, C. H. (1998). Evaluation: Methods for Studying Programs and Policies (2 ${ }^{\text {nd }}$ Ed.). Upper Saddle River, NJ: Prentice Hall.

[157] White, L., \& Millar, R. B. (2014). Quantitative Approaches. In V. Wright-St Clair, D. Reid, S. Shaw, \& J. Ramsbotham (Eds.), Evidence-based Health Practice. South Melbourne: Oxford University Press.

[158] Williams, C. (2007), Research Methods. Journal of Business \& Economic Research, 5(3), 65-72.

[159] Wollmann, H. (2003). Evaluation in Public-Sector Reform: Towards a Third Wave of Evaluation. In Hellmut Wollmann (Ed.), Evaluation in Public-Sector Reform, pp. 1-11, Cheltenham: Edward Elgar.

[160] Wong, G. (2014). Research Questions. In V. Wright-St Clair, D. Reid, S. Shaw \& J. Ramsbotham (Eds.), Evidence-based Health Practice. South Melbourne: Oxford University Press.

[161] Xining, Z. (2002). Interpretivist Research, Positivist Research, and Field Research. Chinese Education and Society, 35(2), 39-46.

[162] Yin, R. K., (1994). Case Study Research Design and Methods: Applied Social Research and Methods Series (2 ${ }^{\text {nd }}$ Ed.). Thousand Oaks, CA: Sage Publications.

[163] Young, M. E., \& Ryan, A. (2020). Postpositivism in Health Professions Education Scholarship. Academic Medicine, 95(5), 695-699.

[164] Zammito, J. H. (2004). A Nice Derangement of Epistemes. Post-positivism in the study of Science from Quine to Latour. Chicago \& London: The University of Chicago Press. 